\title{
Ergopeptine-Sensitive Calcium-Dependent Protein Phosphorylation System in the Brain
}

\author{
${ }^{*}$ Carol A. Stratford, †Stephen K. Fisher, and * $¥$ Tetsufumi Ueda \\ *Department of Pharmacology; $¥$ Neuroscience Laboratory; and $\ddagger$ Mental Health Research Institute, The University of \\ Michigan, Ann Arbor, Michigan, U.S.A.
}

\begin{abstract}
We studied a protein phosphorylation system that is regulated by the dopamine-mimetic ergot bromocriptine. Bromocriptine was found to inhibit selectively the endogenous phosphorylation of a threonine residue(s) in 50,000- and 60,000-dalton proteins in a synaptosome fraction. The bromocriptine-sensitive phosphorylation is stimulated by calcium and by calmodulin, and occurs predominantly in the brain. The inhibitory effect of bromocriptine was not mimicked by 3,4-dihydroxyphenylethylamine or by any of the neurotransmitters and related agents tested, but was mimicked, although less effectively, by other ergots that contain peptide moieties. In the hippocampus, the brain region with the highest con-
\end{abstract}

tent of the 50,000- and 60,000-dalton proteins, the ergopeptine-sensitive protein phosphorylation appears to be localized to interneurons or cell bodies whose axons synapse outside the hippocampus. The results raise the possibility that some of the bromocriptine- and ergopeptineinduced pharmacological effects in the CNS may be mediated by the inhibition of the calcium/calmodulin-dependent phosphorylation of these specific proteins. Key Words: Bromocriptine-Calcium-Calmodulin-Ibotenate-Protein phosphorylation. Stratford C. A. et al. Ergopeptine-sensitive calcium-dependent protein phosphorylation system in the brain. $J$. Neurochem. 42, 842855 (1984).
Protein phosphorylation is involved in the regulation of enzymatic and cellular activities in a variety of biological systems, including the nervous system, where it has been proposed to serve as a mediator of at least some of the physiological effects of calcium (see Krebs and Beavo, 1979; Glass and Krebs, 1980; Greengard, 1981; Cohen, 1982, for reviews). A number of calcium-dependent protein phosphorylation systems in brain tissue have been described (DeLorenzo, 1976; Schulman and Greengard, 1978; Takai et al., 1979; Wrenn et al., 1980); however, a direct relationship between calcium-dependent phosphorylation and neuronal function has yet to be established. In the present study, we investigated interactions between neuroactive agents and calcium-dependent phosphorylation in a synaptosome fraction of rat brain. We report here that the 3,4-dihydroxyphenylethylamine (dopamine)-mimetic ergot bromocriptine (2-Br- $\alpha$-ergocriptine) and other peptide-containing ergots selectively inhibit the calmodulin-stimulated phosphorylation of $50,000-$ and 60,000 -dalton proteins which are highly enriched in the brain. Lesion studies on the guinea pig hippocampus are also presented, and indicate that these phosphoproteins are predominantly localized to interneurons or cell bodies whose axons synapse outside the hippocampus.

These bromocriptine-sensitive phosphoproteins have electrophoretic mobilities in sodium dodecyl sulfate (SDS) similar to those of diphenylhydan-
Received May 9, 1983; accepted September 26, 1983.

Address correspondence and reprint requests to Tetsufumi Ueda, Mental Health Research Institute, 205 Washtenaw Pl., The University of Michigan, Ann Arbor, MI 48109, U.S.A.

The present address of C.A.S. is Department of Anatomy and Cell Biology, The University of Michigan, Ann Arbor, MI 48109, U.S.A. The present address of S.K.F. is Department of CNS Research, Medical Research Division of American Cyanamid, Lederle Laboratories, Pearl River, NY 10965, U.S.A.
Abbreviations used: $\mathrm{BrC}_{-50}, \mathrm{BrC}-\mathrm{P}_{60}$, Bromocriptine-sensitive phosphoproteins with molecular weights of 50,000 and 60,000, respectively; ChAT, Choline acetyltransferase; Dopamine, 3,4-Dihydroxyphenylethylamine; DPH, Diphenylhydantoin; DPH-L, DPH-M, Diphenylhydantoin-sensitive proteins; GABA, $\gamma$-Aminobutyric acid; GAD, Glutamate decarboxylase; KRB, Krebs-Ringer bicarbonate buffer; SDS, Sodium dodecyl sulfate; Serotonin, 5-Hydroxytryptamine. 
toin (DPH)-sensitive phosphoproteins termed DPH$\mathrm{L}$ and DPH-M (DeLorenzo, 1976), the major $\mathrm{Ca}^{2+} /$ calmodulin-dependent phosphoproteins in a synaptosomal membrane fraction (Schulman and Greengard, 1978), and the 51,000- and 62,000-dalton phosphoproteins in the postsynaptic density fraction (Grab et al., 1981). DPH-L and DPH-M have been shown to be present in synaptic vesicle, synaptic junctional complex, postsynaptic density, and synaptic membrane fractions (DeLorenzo, 1980). DeLorenzo and coworkers (DeLorenzo et al., 1979; DeLorenzo, 1980) have provided evidence that $\mathrm{Ca}^{2+} /$ calmodulin-dependent phosphorylation of $\mathrm{DPH}-\mathrm{L}$ and DPH-M is correlated with depolarization-dependent calcium uptake and neurotransmitter release. The bromocriptine-sensitive phosphorylation system is discussed in relation to the above $\mathrm{Ca}^{2+}$ /calmodulin-dependent phosphoproteins as well as with respect to a possible association with a particular neurotransmitter system.

\section{MATERIALS AND METHODS}

\section{Materials}

Male Sprague-Dawley rats (126-150 g) were obtained from Charles River. Male guinea pigs $(350-400 \mathrm{~g})$ were obtained from Buckberg Animals (Tomkins Cove, NY). $\left[\gamma^{32} \mathrm{P}\right] A T P(>5000 \mathrm{Ci} / \mathrm{mmol}),\left[1-{ }^{14} \mathrm{C}\right] \mathrm{L}-$ glutamic acid $(50$ $\mathrm{Ci} / \mathrm{mmol})$, and $\left[{ }^{14} \mathrm{C}\right]$ acetyl-coenzyme $\mathrm{A}(56.6 \mathrm{Ci} / \mathrm{mmol})$ were purchased from Amersham. Acrylamide, $N, N, N^{\prime}, N^{\prime}$-tetramethylene ethylenediamine, and X-ray film (XAR-5) were from Eastman Kodak. $N, N^{\prime}$-Methylene bisacrylamide (electrophoresis grade) was from Polysciences. Ibotenic acid was obtained from Regis Chemical (Morton Grove, IL). Molecular weight standards for SDS gel electrophoresis were from Bio-Rad. SDS, ATP, $\alpha$-chymotrypsin, ergotamine tartrate, $\alpha$-ergocriptine, ergonovine, 2-mercaptoethanol, phosphoserine, and phosphothreonine were from Sigma Chemical. All other chemicals were of reagent quality.

The following were gifts, generously provided by the person or company indicated: bromocriptine (Sandoz Pharmaceuticals, East Hanover, NJ); (+)- and (-)-butaclamol (Ayerst Laboratories, New York, NY); chlorpromazine (Smith, Kline and French, Philadelphia, PA); clonidine $\mathrm{HCl}$ (Boehringer Ingelheim, Ridgefield, CT); dihydroergocriptine (Sandoz Pharmaceuticals); fluphenazine $\mathrm{HCl}$ (E. R. Squibb and Sons, Princeton, NJ); haloperidol (Dr. R. Katz, University of Michigan); metoclopramide $\mathrm{HCl}$ (A. H. Robins, Richmond, VA); molindone (Abbott Laboratories, N. Chicago, IL); phentolamine mesylate (Ciba Pharmaceuticals, Summit, NJ); quipazine (Dr. J. Woods, University of Michigan); spiroperidol (Janssen Pharmaceutica, New Brunswick, NJ); sulpiride (Delagrange Intl., Paris, France); thioridazine $\mathrm{HCl}$ (Sandoz Pharmaceuticals); trifluoperazine dihydrochloride (Smith, Kline and French); yohimbine $\mathrm{HCl}$ (Dr. C. B. Smith, University of Michigan). Purified calmodulin was the gift of Dr. M. E. Gnegy (University of Michigan), and phosphotyrosine was the gift of Dr. S. Cohen (Vanderbilt University). All other chemicals used were of reagent quality.
Krebs-Ringer bicarbonate buffer (KRB) (Daly et al., 1980) was prepared fresh each day and contained the following components (millimolar concentrations): $\mathrm{NaCl}$ (122); $\mathrm{NaHCO}_{3}$ (25); D-glucose (10); $\mathrm{KCl}(3.0) ; \mathrm{KH}_{2} \mathrm{PO}_{4}$ (1.0); $\mathrm{MgSO}_{4}(1.2) ; \mathrm{CaCl}_{2}(1.3)$. The solution was gassed with $95 \% \mathrm{O}_{2}-5 \% \mathrm{CO}_{2}$ to $\mathrm{pH} 7.4$ prior to use.

\section{Preparation of a synaptosome fraction}

A crude syaptosome fraction $\left(\mathbf{P}_{2}\right)$ was prepared from rat cerebral cortex (unless otherwise indicated) using a method similar to that described by Daly et al. (1980). Rats were killed by decapitation. Brains were removed and cortical regions were dissected free of striatal regions and excess white matter. The cortices were then roughly chopped with a scalpel, immersed briefly in ice-cold KRB, drained on a small riylon mesh screen, and weighed. Homogenization was carried out in three volumes of KRB in a teflon-glass homogenizer (five or six strokes, $900 \mathrm{rpm}$ ). The homogenate was centrifuged at $1,000 g_{\max }, 15 \mathrm{~min}$. The resulting supernatant was centrifuged at $20,000 g_{\max }, 20 \mathrm{~min}$. The resulting pellet $\left(\mathrm{P}_{2}\right)$ was resuspended in three volumes of KRB (based on original wet weight) by gentle homogenization by hand.

\section{Standard assay for phosphorylation of the $\mathbf{P}_{2}$ fraction}

Aliquots $\left(50 \mu \mathrm{l}, 60-80 \mu \mathrm{g}\right.$ protein) of the $\mathrm{P}_{2}$ suspension were transferred to tubes on ice containing $35 \mu \mathrm{KRB}$ and $5 \mu \mathrm{l}$ test agent. The mixtures were preincubated at $37^{\circ} \mathrm{C}$ for $2 \mathrm{~min}$ in a shaking water bath. The phosphorylation reaction was initiated by addition of $10 \mu][\gamma$ ${ }^{32}$ P]ATP ( $\left.40 \mu M, 5-10 \mathrm{Ci} / \mathrm{mmol}\right)$. After a 2-min incubation period, the reaction was terminated by addition of $50 \mu \mathrm{l}$ SDS stop solution containing $0.186 \mathrm{M}$ Tris- $\mathrm{HCl}, \mathrm{pH} 6.7$; $9 \%$ SDS; $15 \%$ (vol/vol) glycerol; $12 \%$ 2-mercaptoethanol; and a trace of bromphenol blue (Ueda and Greengard, 1977) followed by immediate placement in a boiling water bath. Modifications to this procedure, when applicable, are indicated in the text and/or figure legends.

\section{Lesions of the guinea pig hippocampus}

Three unilateral infusions of $10 \mu \mathrm{g}$ ibotenic acid, each in $4 \mu \mathrm{l}$ phosphate-buffered saline $(\mathrm{pH} 7.4)$, were administered to seven guinea pigs, as previously described (Fisher et al., 1981). The contralateral side of the hippocampus served as a control. Anodal electrolytic lesions were placed in the fornix-fimbria of six guinea pigs as described by Fisher et al. (1980) to effect bilateral ablation of this pathway. Unoperated animals served as controls for the fornix-fimbria-lesioned animals.

\section{Preparation and phosphorylation of guinea pig hippocampal homogenates}

Ibotenate-treated guinea pigs were sacrificed 13 days postinjection, and those with lesions of the fornix-fimbria, 7-10 days postlesion. Guinea pigs were killed by stunning and exsanguination, followed by removal of the cerebrum and dissection of the hippocampal formation (dentate gyrus and hippocampus proper) from the surrounding tissue. Tissues were weighed and homogenized in three volumes KRB (five or six strokes in a Teflonglass homogenizer, $900 \mathrm{rpm}$ ). An aliquot of this homogenate was then diluted in six and one-half volumes 0.32 $M$ sucrose for all enzyme assays. Immediate preparation and use of the tissues was essential to obtain consistent 
control phosphorylation levels between animals. Twenty microliters of tissue suspension were added to $75 \mu \mathrm{KRB}$ in test tubes resting in an ice bath. Phosphorylation of samples in the presence of bromocriptine $(25 \mu \mathrm{M}$, final concentration) or carrier was carried out as described for the $\mathrm{P}_{2}$ fraction. All tissue samples were assayed in triplicate.

\section{SDS polyacrylamide gel electrophoresis and autoradiography}

Phosphorylated samples $(100-\mu l$ aliquots) were applied to discontinuous SDS polyacrylamide slab gels. The composition of these gels was identical to that described by Ueda and Greengard (1977), except that a $6.9 \%$ acrylamide resolving gel was used unless otherwise indicated. Electrophoresis was carried out at constant voltage (40 $\mathrm{V}$, overnight). Gels were stained, dried, and placed on $\mathrm{X}$ ray film for autoradiography for 2-5 days. In some cases, Cronex intensifying screens (DuPont) were employed.

Quantification of ${ }^{32} \mathrm{P}$-phosphate incorporation into protein bands was performed as described by Ueda et al. (1973). Darkness of the autoradiograph was measured by a scanning densitometer and expressed as arbitrary units. The arbitrary units were converted to fmol of incorporated ${ }^{32} \mathrm{P}$-phosphate by determining the radioactivity present in representative protein bands from the same gel in a liquid scintillation counter.

\section{Peptide mapping}

Phosphorylated samples were subjected to SDS-polyacrylamide gel electrophoresis as described above. Following electrophoresis, the unstained gels were soaked in several changes of acetic acid-methanol-water (1:5:4), dried, and autoradiographed. With the autoradiograph as a guide, the pieces of gel containing phosphoproteins were excised, scraped of paper backing, and the proteins were eluted as described by Huttner and Greengard (1979). Elution was carried out at $37^{\circ} \mathrm{C}$ for $20 \mathrm{~h}$ in $50 \mathrm{mM}$ ammonium bicarbonate-1 $\mathrm{m} M$ dithiothreitol containing 75 $\mu \mathrm{g} / \mathrm{ml}$ each trypsin and chymotrypsin $(1 \mathrm{ml} /$ protein band) plus a trace of phenol red. The eluate was removed and fresh elution buffer added for further incubation at $37^{\circ} \mathrm{C}$ for $6 \mathrm{~h}$. (Concentration of enzymes was reduced to $25 \mu \mathrm{g}$ / ml during the second elution.) The eluates were pooled and lyophilized in a rotary evaporator (Savant). Samples were dissolved in 10-50 $\mu$ l of high-voltage electrophoresis buffer composed of $10 \%$ acetic acid and $1 \%$ pyridine ( $\mathrm{vol} / \mathrm{vol})$, pH 3.5. Samples were then spotted on cellulose thin-layer plates (Eastman Kodak 13255), and subjected to high-voltage electrophoresis $(1,000 \mathrm{~V}, 30 \mathrm{~min})$. The plates were air-dried and subjected to ascending chromatography in the second dimension using a solution of $n$-butanol-pyridine-acetic acid-water (37.5:25:7.5:30). Dried thin-layer plates were placed on X-ray film for autoradiography.

\section{Phosphoamino acid analysis}

The $\mathrm{P}_{2}$ fraction was phosphorylated in the absence or presence of $25 \mu M$ bromocriptine, as described above, except that the specific activity of $\left[\gamma^{32} \mathrm{P}\right]$ ATP was increased to $20 \mathrm{Ci} / \mathrm{mmol}$. Samples were electrophoresed at $180 \mathrm{~V}$ for $18 \mathrm{~h}$ on $27-\mathrm{cm}$ long SDS gels $(6.9 \%)$. The gels were rinsed briefly with distilled water, immediately dried, and subjected to autoradiography. Those portions of the gel corresponding to the positions of the bromo- criptine-sensitive 50,000- and 60,000-dalton phosphoproteins were excised, using the autoradiograph as a guide. The proteins were extracted from the gels with $0.1 \%$ SDS-0.05 $\mathrm{M} \mathrm{NH}_{4} \mathrm{CO}_{3}$, precipitated with $20 \%$ trichloroacetic acid, and the precipitates washed successively with ethanol and ethanol-ether $(1: 1)$ at $-10^{\circ} \mathrm{C}$, as described by Beemon ad Hunter (1978). The washed precipitates were dissolved in $1 \mathrm{ml}$ of $98 \%$ formic acid, lyophilized, redissolved in $1 \mathrm{ml}$ of $6 \mathrm{M} \mathrm{HCl}$, and hydrolyzed in vacuo at $110^{\circ} \mathrm{C}$ for $2 \mathrm{~h}$, as described by Eckhart et al. (1979). The samples were then lyophilized and dissolved in $60 \mu$ ] of pH 2 electrophoresis buffer [glacial acetic acid-formic acid (88\%)-water, 78:25:897] containing $5 \mathrm{mM}$ each authentic phosphoserine, phosphothreonine, and phosphotyrosine. Ten microliters of each sample were applied to separate thin-layer cellulose plates (Eastman Kodak $13255)$ and electrophoresed toward the anode $(1,000 \mathrm{~V}$, $90 \mathrm{~min}$ ). The plates were then dried and chromatographed in the second dimension in isobutyric acid-0.05 M $\mathrm{NH}_{4} \mathrm{CO}_{3}$ (5:3). Phosphoamino acid markers were detected by ninhydrin staining. Autoradiography was carried out at $-70^{\circ} \mathrm{C}$, using intensifying screens.

\section{Marker enzyme assays}

Choline acetyltransferase (EC 2.3.1.6, ChAT) activity was measured in guinea pig hippocampal homogenates by the method of Fonnum (1975). Glutamate decarboxylase (EC 4.1.1.15, GAD) activity was measured in the homogenates as described previously (Fisher et al., 1980) with the exceptions that the final concentration of sodium L-glutamate was $20 \mathrm{~m} M$ and incubations were terminated after $60 \mathrm{~min}$. All tissue samples were assayed in triplicate. Paired Student's $t$-tests were used to compare means of data from ibotenate-treated guinea pigs, since both control and treated tissues were taken from each animal. Unpaired Student's $t$-tests were employed for comparisons between groups of animals used in the fornix-fimbria lesion studies.

\section{Protein determination}

Protein concentration was determined by the method of Lowry et al. (1951), with bovine serum albumin as standard.

\section{RESULTS}

\section{Effects of neurotransmitters and agonists on synaptosome protein phosphorylation}

Figure 1 shows the results of an experiment in which a number of neurotransmitters and neurotransmitter agonists were tested for effects on phosphorylation of proteins in a crude synaptosome $\left(\mathrm{P}_{2}\right)$ fraction of rat cerebral cortex. Bromocriptine (25 $\mu M)$, an ergot with dopamine-mimetic properties (Fuxe et al., 1978; Kebabian and Calne, 1979), caused a marked inhibition of the phosphorylation of 50,000- and 60,000-dalton proteins, and a slight inhibition of the phosphorylation of a 150,000 dalton protein $\left(\mathrm{P}_{150}\right)$. However, neither dopamine nor any of the other neurotransmitters or agonists tested significantly altered the phosphorylation of these or other proteins in the $\mathrm{P}_{2}$ preparation under the conditions employed in this study. In other ex- 


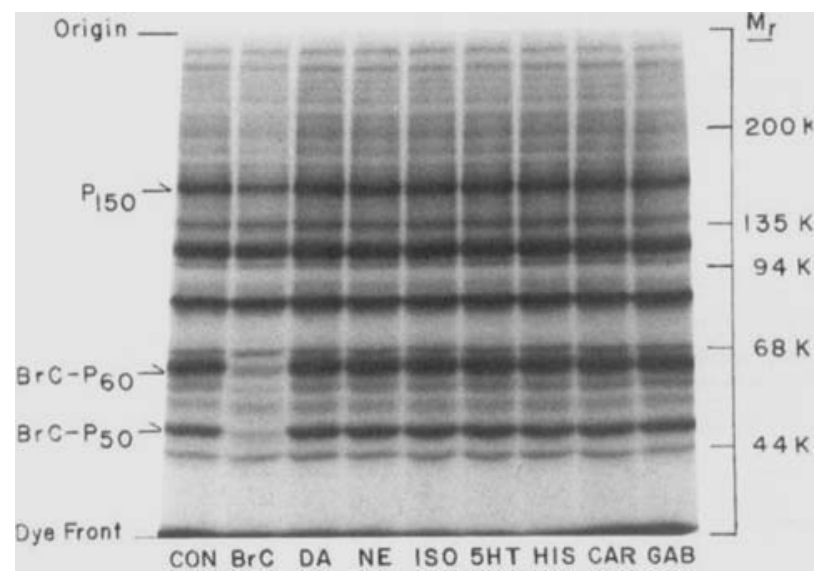

FIG. 1. Effects of various neurotransmitters and agonists on protein phosphorylation in the $\mathrm{P}_{2}$ fraction of rat cortex. Aliquots of the $P_{2}$ fraction ( $60 \mu \mathrm{g}$ protein) were subjected to phosphorylation for $2 \mathrm{~min}$ in the absence (control; CON) or presence of $25 \mu M$ bromocriptine (BrC), dopamine (DA), norepinephrine (NE), isoproterenol (ISO), serotonin (5HT), histamine (HIS), carbachol (CAR), or GABA (GAB), as described in Materials and Methods. Aliquots ( $40 \mu \mathrm{g}$ protein) of the phosphorylated samples were subjected to SDS-gel electrophoresis (40 V, $16 \mathrm{~h}$; followed by $100 \mathrm{~V}, 1 \mathrm{~h})$ and autoradiography as described in Materials and Methods. BrC- $P_{50}$ and BrC- $\mathrm{P}_{60}$, Bromocriptine-sensitive phosphoproteins with approximate molecular weights of 50,000 and 60,000 , respectively. $200 \mathrm{~K}, 200,000 ; 135 \mathrm{~K}, 135,000 ; 94 \mathrm{~K}, 94,000 ; 68 \mathrm{~K}, 68,000$; $44 \mathrm{~K}, 44,000$.

periments not shown here, the potent dopamine agonist apomorphine $(25 \mu M)$ caused only a slight inhibition of the phosphorylation of these proteins. Moreover, the bromocriptine-induced inhibition was not prevented by any of the dopamine antagonists tested (data not shown). These observations suggest that the inhibitory effect of bromocriptine is not mediated through dopamine receptors.

The major bromocriptine-sensitive phosphoproteins with molecular weights of 50,000 and 60,000 will hereafter be referred to as $\mathrm{BrC}-\mathrm{P}_{50}$ and $\mathrm{BrC}$ $\mathrm{P}_{60}$, respectively. Experiments were carried out to determine the nature of the bromocriptine-induced reduction of phosphorylation of these proteins. Addition of bromocriptine to the reaction mixture after preincubation of the $\mathrm{P}_{2}$ fraction with $\left[\gamma_{-}{ }^{32} \mathrm{P}\right] \mathrm{ATP}$, followed by additional incubation, did not result in a change in the state of phosphorylation of these proteins as compared with control (data not shown). This experiment suggests that the effect of bromocriptine on $\mathrm{BrC}-\mathrm{P}_{50}$ and $\mathrm{BrC}-\mathrm{P}_{60}$ phosphorylation does not reflect activation of a specific protein phosphatase. The possibility that bromocriptine causes the disappearance of these phosphoproteins via activation of a specific phosphoprotein protease was tested by subjecting the phosphorylated samples to electrophoresis on SDS-polyacrylamide (15\%) gels. No appearance of new lower molecular weight phosphoprotein species in bromocriptine- treated samples was observed. In addition, cyclic AMP had no effect on the state of phosphorylation of $\mathrm{BrC}-\mathrm{P}_{50}$ and $\mathrm{BrC}-\mathrm{P}_{60}$ (data not shown). On the basis of these observations, we conclude that bromocriptine directly inhibits the protein phosphorylation reaction.

\section{Time course of phosphorylation of $\mathrm{BrC}-\mathrm{P}_{50}$ and $\mathrm{BrC}-\mathrm{P}_{60}$}

To characterize further the bromocriptine-sensitive phosphorylation, the time course of net phosphorylation of $\mathrm{BrC}-\mathrm{P}_{50}$ and $\mathrm{BrC}-\mathrm{P}_{60}$ was determined in the presence of $4 \mu M$ ATP, both in the absence and in the presence of $25 \mu M$ bromocriptine. As shown in Fig. 2, maximal phosphorylation of both proteins occurred within $15 \mathrm{~s}$ after addition of ATP to the reaction mixture. Bromocriptine decreased both the rates and the final levels of net phosphorylation of $\mathrm{BrC}-\mathrm{P}_{50}$ and $\mathrm{BrC}-\mathrm{P}_{60}$. When a saturating concentration of ATP $(500 \mu M)$ was used, bromocriptine had little effect on the final levels, although it reduced the rates of phosphorylation substantially (data not shown). The final levels of phosphorylation of both proteins were approximately 25 -fold higher under the ATP-saturating conditions than under standard conditions. Also apparent from these experiments is the relatively slow turnover of ${ }^{32} \mathrm{P}$-phosphate on these phosphoproteins. Thus, after an incubation period of $10 \mathrm{~min}$, only a slight decrease in their phosphorylation levels was observed (Fig. 2), indicating that the $\mathrm{P}_{2}$ preparation contains relatively low levels of $\mathrm{BrC}-\mathrm{P}_{50}$ and/or BrC-P $_{60}$ phosphatase.

\section{Effect of ATP concentration on phosphorylation of $\mathrm{BrC}-\mathrm{P}_{50}$ and $\mathrm{BrC}-\mathrm{P}_{60}$}

The phosphorylation of $\mathrm{BrC}-\mathrm{P}_{50}$ and $\mathrm{BrC}-\mathrm{P}_{60}$ as a function of ATP concentration is shown in Fig. 3. In this experiment, the incubation was carried out for $5 \mathrm{~s}$ in an effort to obtain initial rates. Maximal phosphorylation of both proteins occurred with ATP concentrations $>50 \mu M$. From the Hanes plots of these data shown in the insets of Fig. 3, apparent $K_{\mathrm{m}}$ 's of the phosphorylation of BrC-P $\mathrm{P}_{50}$ and $\mathrm{BrC}-\mathrm{P}_{60}$ for ATP were determined to be 17.6 $\mu M$ and 15.5 $\mu M$, respectively. Apparent $V_{\max }$ 's of the reactions were determined to be $131 \mathrm{fmol} \cdot \mathrm{s}^{-1}$ and 122 fmol $\cdot \mathrm{s}^{-1}$, respectively.

\section{Ion requirements for phosphorylation of $\mathrm{BrC}-\mathrm{P}_{50}$ and $\mathrm{BrC}-\mathrm{P}_{60}$}

Under standard conditions, phosphorylation of the $\mathrm{P}_{2}$ fraction was carried out in the presence of a $\mathrm{KRB}$ solution approximating the ionic composition of the extracellular fluid in the brain (Dingledine et al., 1980). In experiments designed to determine ion requirements of the bromocriptine-sensitive phosphorylation reaction, it was found that addition of EGTA to the reaction mixture caused a marked decrease in the phosphorylation of both BrC- $\mathrm{P}_{50}$ and 
FIG. 2. Time course of phosphorylation of $\mathrm{BrC}-\mathrm{P}_{50}$ and $\mathrm{BrC}-\mathrm{P}_{60}$. Aliquots ( $50 \mu \mathrm{g}$ protein) of the $P_{2}$ fraction were incubated with $4 \mu M$ ATP (final concentration) for various periods of time in the absence (O) or presence (-) of $25 \mu \mathrm{M}$ bromocriptine, as described in Materials and Methods. Aliquots (50 $\mu \mathrm{g}$ protein) of the reaction mixture were subjected to SDS-gel electrophoresis and autoradiography. Quantitation of ${ }^{32} \mathrm{P}$-phosphate into protein bands was carried out as described in Materials and Methods. A: BrC- $\mathrm{P}_{60}$. B: BrC- $\mathrm{P}_{50}$.
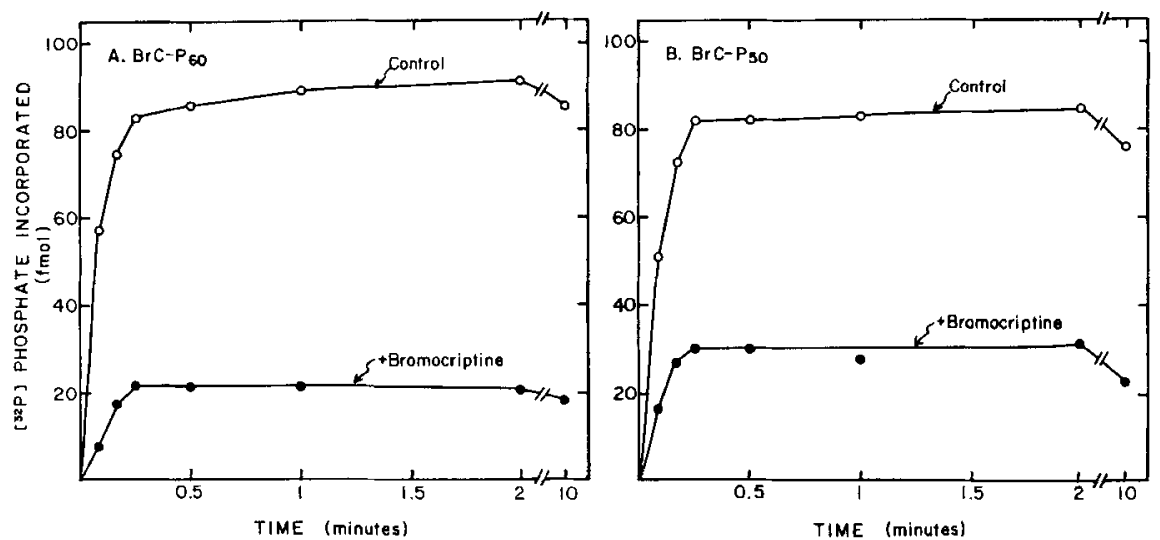

BrC- $\mathrm{P}_{60}$ (data not shown). Therefore, calcium dependence of the reaction was investigated further. Figure 4 shows the effect of varying the calcium concentration in the presence of $3 \mathrm{~m} M$ EGTA on the phosphorylation of $\mathrm{BrC}-\mathrm{P}_{50}$ and $\mathrm{BrC}-\mathrm{P}_{60}$ in the presence of $0 \mathrm{~m} M, 1.2 \mathrm{~m} M$, and $10 \mathrm{~m} M$ magnesium. From these data, it is clear that calcium markedly stimulates the phosphorylation of $\mathrm{BrC}-\mathrm{P}_{50}$ and $\mathrm{BrC}$ $\mathrm{P}_{60}$. The free calcium concentrations required for one-half maximal stimulation of phosphorylation, calculated as described by Nanninga and Kempen
(1971), were in the range of $2-7 \mu M$. Figure 4 also demonstrates the magnesium requirement of the protein phosphorylation.

Addition of purified calmodulin caused a substantial increase in the phosphorylation of $\mathrm{BrC}-\mathrm{P}_{50}$ and $\mathrm{BrC}-\mathrm{P}_{60}$ (Table 1). The calmodulin-stimulated activity was also inhibited by bromocriptine. These results suggest that the bromocriptine-sensitive phosphorylation of $\mathrm{BrC}-\mathrm{P}_{50}$ and $\mathrm{BrC}-\mathrm{P}_{60}$ is catalyzed by calcium/calmodulin-dependent protein kinase(s).
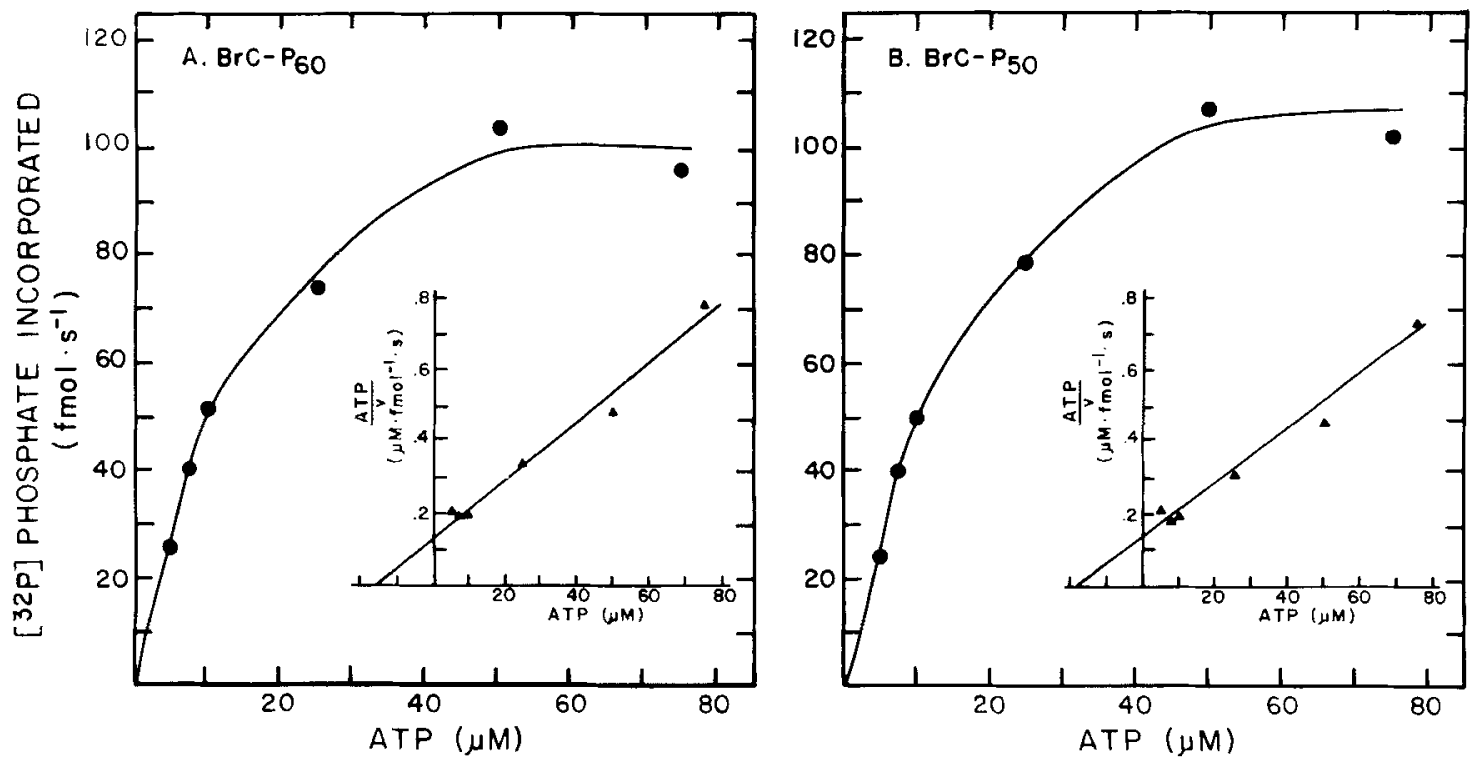

FIG. 3. Effects of various concentrations of ATP on phosphorylation of $B r C-P_{50}$ and $B r C-P_{60}$. Aliquots (69 $\mu g$ protein) of the $P_{2}$ fraction were preincubated at $37^{\circ} \mathrm{C}$ for $2 \mathrm{~min}$. [ $\left.\gamma^{-32} \mathrm{P}\right] \mathrm{ATP}$ was added to each sample to yield the final concentrations indicated, and the reaction terminated after $5 \mathrm{~s}$ incubation time. SDS-gel electrophoresis, autoradiography, and quantitation of ${ }^{32} \mathrm{P}-$ phosphate incorporated into protein bands were carried out as described in Materials and Methods. Insets show the data plotted as the Hanes transformation (Cornish-Bowden, 1979) of the Michaelis-Menten equation: $(S / V)=\left(K_{m} / V_{\max }\right)+\left(S / V_{\max }\right)$. The $x$-intercept represents $-K_{\mathrm{m}}(\mathrm{app})$; the $y$-intercept represents $-K_{\mathrm{m}}(\mathrm{app}) / V_{\max }(\mathrm{app})$, and the slope of the line equals $1 / V_{\max }(\mathrm{app})$. Lines drawn are from linear regression by least squares analysis of the data. $A$ : $B r C-P_{60}, K_{m}(a p p)=15.5 \mu M ; V_{\max }(a p p)=122$ $\mathrm{fmol} \cdot \mathrm{s}^{-1}$. B: BrC- $\mathrm{P}_{50}, K_{\mathrm{m}}(\mathrm{app})=17.6 \mu M ; V_{\max }(\mathrm{app})=131 \mathrm{fmol} \cdot \mathrm{s}^{-1}$. 

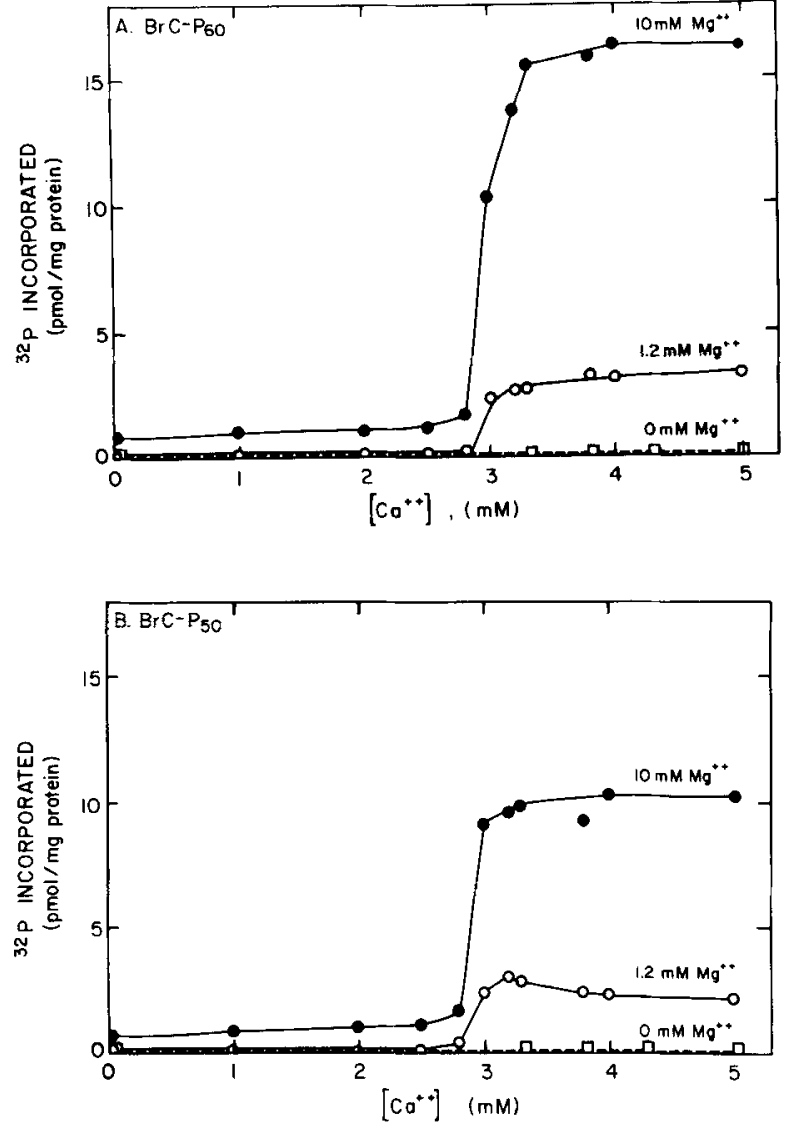

FIG. 4. Effects of various concentrations of calcium ions on phosphorylation of $\mathrm{BrC}-\mathrm{P}_{50}$ and $\mathrm{BrC}-\mathrm{P}_{60}$. The $\mathrm{P}_{2}$ fraction was resuspended in calcium- and magnesium-free KRB. Aliquots $(40 \mu \mathrm{g})$ were incubated with $\left[\gamma^{-32} \mathrm{P}\right] A T P$ in the presence of 3 mM EGTA and of the final concentrations of magnesium and calcium indicated, as described in Materials and Methods. Phosphorylation of samples, autoradiography, and quantitation of ${ }^{32} \mathrm{P}$-phosphate incorporation into protein bands were carried out as described in Materials and Methods. A: BrC- $P_{60}$. B: BrC- $\mathrm{P}_{50} \cdot(\square), 0 \mathrm{mM} \mathrm{Mg}{ }^{2+} ;(O), 1.2 \mathrm{mM} \mathrm{Mg}^{2+} ;(0)$, $10 \mathrm{mM} \mathrm{Mg}{ }^{2+}$.

\section{Phosphoamino acid analysis of BrC-P 50} and $\mathrm{BrC}-\mathrm{P}_{60}$

To determine the ${ }^{32} \mathrm{P}$-phosphoamino acid residues in $\mathrm{BrC}-\mathrm{P}_{50}$ and $\mathrm{BrC}-\mathrm{P}_{60}$, phosphorylated $\mathrm{BrC}-\mathrm{P}_{50}$ and $\mathrm{BrC}-\mathrm{P}_{60}$ were separated from other phosphoproteins by SDS-gel electrophoresis, eluted from gels, and subjected to partial acid hydrolysis. The hydrolysates were then analyzed for $\left[{ }^{32} \mathrm{P}\right]$ phosphoserine, $\left[{ }^{32} \mathrm{P}\right]$ phosphothreonine, and $\left.{ }^{32} \mathrm{P}\right]$ phosphotyrosine by electrophoresis in the first dimension and chromatography in the second dimension. As shown in Fig. 5, bromocriptine-sensitive phosphorylation occurs on a threonine residue(s) of both BrC- $\mathrm{P}_{50}$ and BrC- $\mathrm{P}_{60}$. Although to lesser degrees, both of the proteins were also phosphorylated on a serine residue(s); however, the serine phosphorylation was not affected by bromocriptine. Whether the phosphoserine resides in $\mathrm{BrC}-\mathrm{P}_{50}$ and $\mathrm{BrC}-\mathrm{P}_{60}$ or in contaminating proteins with similar molecular weights is not known at present.

Phospho-peptide mapping of $\mathrm{BrC}-\mathrm{P}_{50}$ and $\mathrm{BrC}-\mathrm{P}_{60}$

The similarities in the phosphorylation of $\mathrm{BrC}$ $\mathrm{P}_{50}$ and $\mathrm{BrC}-\mathrm{P}_{60}$ noted in the experiments described above indicated that the proteins themselves might be similar. Therefore, to compare further $\mathrm{BrC}-\mathrm{P}_{50}$ and $\mathrm{BrC}-\mathrm{P}_{60}$, the phosphoproteins were subjected to analysis by peptide mapping as described in $\mathrm{Ma}$ terials and Methods. Figure 6 shows the phosphorylated peptide fragments produced after the tryptic/ chymotryptic digestion. It appears that $\mathrm{BrC}-\mathrm{P}_{50}$ and BrC- $\mathrm{P}_{60}$ share many identical or highly similar phosphopeptides (labeled 1-6). Although precise quantitative comparisons could not be made between plates due to differential recovery of samples from the original gel, a close examination of the changes in the phosphopeptide patterns indicates that bromocriptine inhibited ${ }^{32} \mathrm{P}$-phosphate incorporation into most, but not all, of the phosphopeptides. Bromocriptine had relatively small effects on the phosphorylation of the peptide fragments labeled 8 and 9 of $\mathrm{BrC}-\mathrm{P}_{60}$ and of the fragments labeled 10 and 11 of $\mathrm{BrC}-\mathrm{P}_{50}$. It is therefore likely that these phosphopeptides contain phosphoserine residue(s).

Tissue distribution of bromocriptine-sensitive protein phosphorylation

Various tissue homogenates were examined for bromocriptine-sensitive phosphorylation of 50,000 and 60,000-dalton proteins. As shown in Fig. 7A and $\mathbf{B}$, the bromocriptine-sensitive phosphorylation system is most highly concentrated in the brain. It was not detected in nonnervous tissues such as heart, liver, kidney, lung, and spleen. Although each of these tissues has a phosphoprotein whose electrophoretic mobility is indistinguishable from that of $\mathrm{BrC}-\mathrm{P}_{50}$, its phosphorylation is not bromocriptine-sensitive. It may be noted, however, that adrenal tissue exhibits bromocriptine-sensitive phosphorylation of a 50,000 -dalton protein.

The distribution of $\mathrm{BrC}-\mathrm{P}_{50}$ and $\mathrm{BrC}-\mathrm{P}_{60}$ within some brain regions is shown in Fig. 8. The bromocriptine-sensitive $\mathrm{BrC}-\mathrm{P}_{60}$ phosphorylation system is present in all of the brain regions tested; however, there are regional differences in their specific contents. Thus, the phosphorylation of $\mathrm{BrC}-\mathrm{P}_{60}$ is the highest in the hippocampus, followed by the cortex and striatum, and is lowest in the hypothalamus. With the exception of the cerebellum, the distribution of $\mathrm{BrC}-\mathrm{P}_{50}$ is roughly parallel to that of $\mathrm{BrC}$ $P_{60}$. The cerebellum has a relatively much lower level of $\mathrm{BrC}-\mathrm{P}_{50}$; instead, a bromocriptine-sensitive 56,000 -dalton phosphoprotein is prominent. This phosphorylation system is much more abundant in the cerebellum than in the other regions examined. In the hypothalamus, the 56,000 -dalton protein is the most prominent phosphoprotein component. The pituitary, which is not part of the brain proper, 


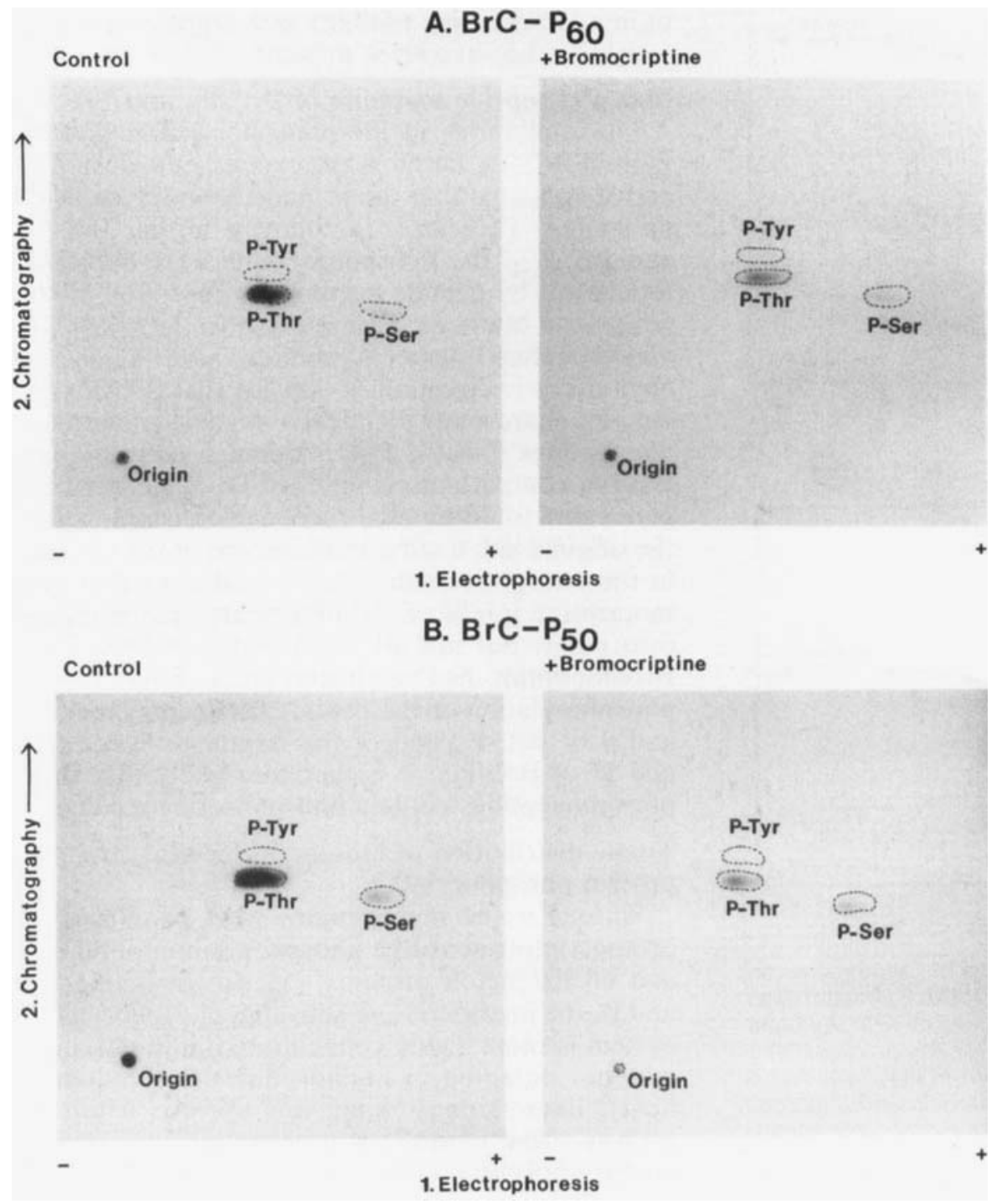

FIG. 5. Analysis of phosphoamino acid residues in $\mathrm{BrC}-\mathrm{P}_{50}$ and $\mathrm{BrC}-\mathrm{P}_{60}$ by electrophoresis and chromatography on thinlayer cellulose. Aliquots of $P_{2}$ fraction prepared from rat cortex (150 $\mathrm{\mu g}$ protein) were subjected to phosphorylation in the absence or presence of $25 \mu \mathrm{M}$ bromocriptine, in a final volume of $0.2 \mathrm{ml}$, as described in Materials and Methods. Following electrophoresis (180 V, 20 h) on $27-\mathrm{cm}$ long gels, the $\mathrm{BrC}-\mathrm{P}_{50}$ and $\mathrm{BrC}-\mathrm{P}_{60}$ bands were identified by autoradiography; the portions of the gels containing $\mathrm{BrC}-\mathrm{P}_{50}$ and $\mathrm{BrC} \mathrm{P}_{60}$ were excised and extracted from the gel with $0.1 \%$ SDS-0.05 $\mathrm{M} \mathrm{NH}_{4} \mathrm{CO}_{3}$, followed by acid hydrolysis, as described in detail in Materials and Methods. The lyophilized samples were dissolved in a pH 2 electrophoresis buffer containing $5 \mathrm{mM}$ each authentic phosphoserine, phosphothreonine, and phosphotyrosine, spotted on TLC plates, and analyzed by electrophoresis in the first dimension and by chromatography in the second dimension, as described in Materials and Methods. P-Ser, Phosphoserine; P-Thr, phosphothreonine; P-Tyr, phosphotyrosine. + , anode; -, cathode.

does not appear to possess a bromocriptine-sensitive phosphorylation system.

\section{Cellular localization of BrC-P ${ }_{50}$ and BrC-P 60}

To investigate the cellular localization of $\mathrm{BrC}-\mathrm{P}_{50}$ and $\mathrm{BrC}-\mathrm{P}_{60}$ within the brain, we carried out lesion studies on the guinea pig hippocampus. In these studies ibotenic acid, a toxin that selectively destroys neuronal cell bodies but spares nerve terminals and axons of passage (Schwarcz et al., 1979; Kohler et al., 1979; Fisher et al., 1981), was injected into one side of the guinea pig hippocampus. Thirteen days postlesion, the two sides were compared for bromocriptine-sensitive protein phosphorylation and marker enzymes as described below. In addition, the effects of electrolytic lesions of the fornixfimbria on protein phosphorylation and marker enzyme activities in the hippocampus were investi- gated. In both series of experiments, hippocampal homogenates were used for the protein phosphorylation assays.

Ibotenate lesions of the hippocampus. Following unilateral intrahippocampal injection of ibotenate, the lesioned side of the hippocampus was shrunken in appearance and weighed $26 \%$ less than the control side. In homogenates obtained from the lesioned hippocampus, the specific activity of GAD, a marker for intrinsic $\gamma$-aminobutyric acid (GABA)ergic neurons (Storm-Mathisen, 1972), was reduced by $40 \%$. However, ChAT activity was not significantly reduced following ibotenate treatment (Table 2), confirming the selective toxicity of this agent. The concentration of protein $/ \mathrm{mg}$ wet weight was also not altered by the lesion (Table 2).

Incubation of guinea pig hippocampal homogenates in the presence of $\left[\gamma^{32} \mathrm{P}\right] \mathrm{ATP}$ resulted in the 
TABLE 1. Effect of calmodulin on phosphorylation of $B r C-P_{50}$ and $B r C-P_{60}$

\begin{tabular}{|c|c|c|c|c|}
\hline \multirow{3}{*}{$\begin{array}{l}\text { Bromocriptine } \\
\qquad(\mu M)\end{array}$} & \multicolumn{4}{|c|}{$\begin{array}{l}\text { Phosphorylation } \\
\text { (fmol }{ }^{22} \text { P-phosphate) }\end{array}$} \\
\hline & \multicolumn{2}{|c|}{ Control } & \multicolumn{2}{|c|}{ + Calmodulin } \\
\hline & $\mathrm{BrC}-\mathrm{P}_{60}$ & $\mathrm{BrC}-\mathrm{P}_{50}$ & $\mathrm{BrC}-\mathrm{P}_{60}$ & BrC- $P_{50}$ \\
\hline 0 & 74 & 63 & 295 & 359 \\
\hline 100 & 24 & 23 & 91 & 77 \\
\hline
\end{tabular}

Phosphorylation was carried out under standard conditions as described in Materials and Methods, except that purified calmodulin $(1 \mu \mathrm{g})$ was added to some samples prior to the addition of carrier or bromocriptine. Quantitation of ${ }^{32} \mathrm{P}$-phosphate was carried out as described in Materials and Methods. $40 \mu \mathrm{g}$ of protein were present in each sample.

rapid appearance of label in several phosphoproteins, the most prominent being $\mathrm{BrC}-\mathrm{P}_{50}$ and $\mathrm{BrC}$ $\mathrm{P}_{60}$ (Fig. 9). Inclusion of bromocriptine in the assay resulted in a selective inhibition of the phosphorylation of these two proteins by 57-69\% (Table 2). (Differences between groups were not statistically significant.) Ibotenate lesion of the hippocampus resulted in a marked reduction in the basal phosphorylation of $\mathrm{BrC}-\mathrm{P}_{50}(55 \%)$ and $\mathrm{BrC}-\mathrm{P}_{60}(51 \%)$
(Table 2). However, the percentage inhibition of phosphorylation resulting from addition of bromocriptine to homogenates prepared from the lesioned side of the hippocampus was comparable to that obtained from the control side (Table 2). Thus, the structures remaining undestroyed by the neurotoxin retain a functional bromocriptine-sensitive protein phosphorylation system.

Fornix-fimbria lesions. Transection of the fornixfimbria resulted in a $71 \%$ reduction of ChAT activity, an indicator of the structural integrity of this pathway (Lewis et al., 1967). However, the lesion had no effect on hippocampal wet weight, protein content, or GAD activity (Table 2). Similarly, neither the basal phosphorylation of $\mathrm{BrC}-\mathrm{P}_{50}$ or $\mathrm{BrC}-$ $\mathrm{P}_{60}$ nor the magnitude of bromocriptine inhibition was affected by the lesion (Table 2; Fig. 9).

\section{Effects of other ergots and centrally active agents on $\mathrm{BrC}-\mathrm{P}_{50}$ and $\mathrm{BrC}-\mathrm{P}_{60}$}

Since dopamine (Fig. 1) and the potent dopamine agonist apomorphine (data not shown) failed to mimic the inhibitory effect of bromocriptine on the protein phosphorylation, it is unlikely that the inhibitory effect can be ascribed to the dopaminergic properties of the ergot. Structurally, bromocriptine
FIG. 6. Peptide mapping of BrC$P_{50}$ and $B r C-P_{60}$. The $P_{2}$ fraction was prepared from rat cortex and aliquots phosphorylated in the absence or presence of $25 \mu M$ bromocriptine. Phosphorylated $\mathrm{BrC}-\mathrm{P}_{50}$ and $\mathrm{BrC}-\mathrm{P}_{60}$ were extracted from SDS-gels and subjected to exhaustive trypsin/chymotrypsin digestion as described in Materials and Methods. Samples were applied to cellulose thin-layer plates at small arrows, and phosphorylated peptides were separated by electrophoresis followed by ascending chromatography in dimensions indicated in the figure, as described in Materials and Methods. Shown here are autoradiographs of thinlayer plates. A: Phosphopeptides of $\mathrm{BrC}-\mathrm{P}_{60}$ phosphorylated in the absence (left) and presence (right) of bromocriptine. B: Phosphopeptides of BrC-P $P_{50}$ phosphorylated in the absence (left) and presence (right) of bromocriptine.

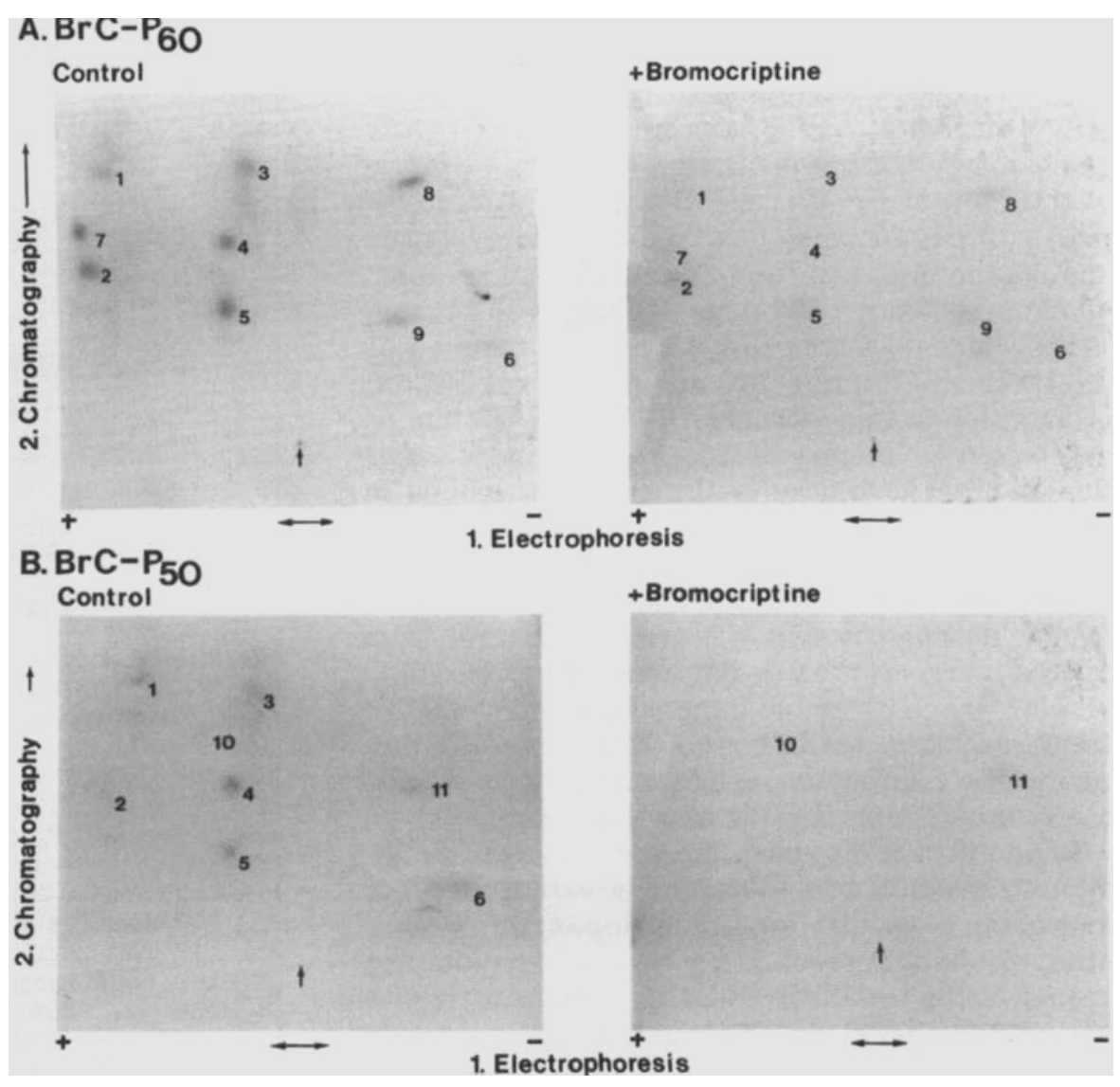



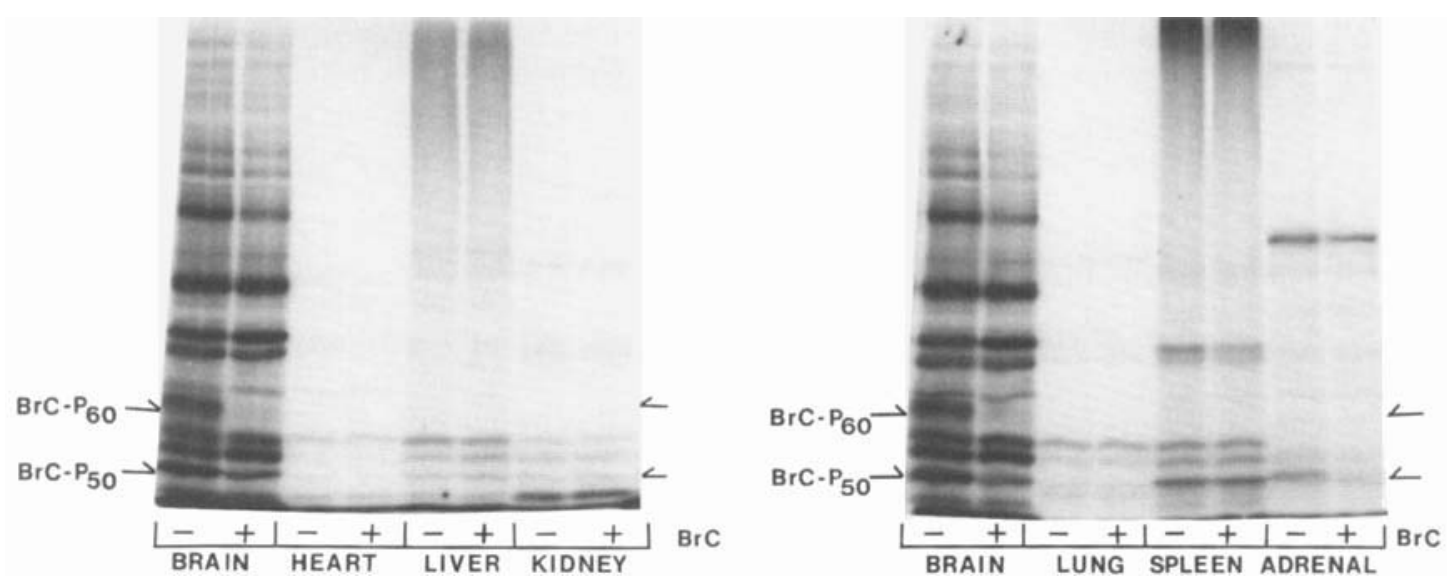

FIG. 7. Tissue specificity of bromocriptine-sensitive phosphorylation of $\mathrm{BrC}-\mathrm{P}_{50}$ and $\mathrm{BrC}-\mathrm{P}_{60}$. Various tissues as indicated were homogenized in three volumes of KRB, and a subcellular fraction was prepared in the same manner as for the $P_{z}$ fraction of rat cortex. Aliquots of the fraction (brain, $56 \mu \mathrm{g}$ protein; heart, $70 \mu \mathrm{g}$ protein; liver, $88 \mu \mathrm{g}$ protein; kidney, $100 \mu \mathrm{g}$ protein; spleen, $113 \mu \mathrm{g}$ protein; and adrenal gland, $20 \mu \mathrm{g}$ protein) were subjected to phosphorylation in the absence or presence of $100 \mu \mathrm{M}$ bromocriptine (BrC), followed by SDS-gel electrophoresis (40 V, $18 \mathrm{~h}$ ) and autoradiography, as described in Materials and Methods. A (left): Comparison of brain, heart, liver, and kidney. B (right): Comparison of brain, lung, spleen, and adrenal.

is classified in a group of ergots termed ergopeptines, which contain peptide moieties substituted on the ergoline ring structure (Rall and Schleifer, 1980). To determine whether the inhibitory effect of bromocriptine is attributable to the ergoline ring structure, the peptide moiety, or to both, various ergot compounds were tested for their capacities to inhibit the phosphorylation of $\mathrm{BrC}-\mathrm{P}_{50}$ and $\mathrm{BrC}-\mathrm{P}_{60}$. As shown in Fig. 10 and Table 3, those ergots that possess peptide moieties- $\alpha$-ergocriptine, dihydroergocriptine, and ergotamine-were slightly less potent than bromocriptine in inhibiting phosphorylation of $\mathrm{BrC}-\mathrm{P}_{50}$ and $\mathrm{BrC}-\mathrm{P}_{60}$. Those ergots that lack peptide moieties, such as methysergide and ergonovine, had little or no effect. The dopamine-mimetic ergot lergotrile (Kebabian and Calne, 1979), which does not possess a peptide moiety, was relatively ineffective in causing the inhibition; bromocriptine was more than 10 times as potent as was lergotrile. It appears that the presence of a particular peptide moiety in the ergots is crucial in causing a potent and specific inhibition of the phosphorylation of $\mathrm{BrC}-\mathrm{P}_{50}$ and $\mathrm{BrC}-\mathrm{P}_{60}$. Thus, although bromocriptine was the most potent of all agents tested, its potency was not greatly different from that of $\alpha$-ergocriptine or dihydroergocriptine, both of which have a peptide moiety identical to that of bromocriptine. On the other hand, ergotamine, which has a different peptide moiety, was significantly less potent than the above ergopeptines.

In an effort to establish the specificity of the inhibitory effect of bromocriptine, a variety of other neuroactive agents, including dopamine antagonists, $\alpha$ - and $\beta$-adrenergic agents, and serotonergic agents, were tested for their capacities to inhibit phosphorylation of $\mathrm{BrC}-\mathrm{P}_{50}$ and $\mathrm{BrC}-\mathrm{P}_{60}$. As shown in Table 3, none of these agents caused as potent an inhibition as did bromocriptine. Among all the nonergot agents tested, spiroperidol, a potent dopamine antagonist, was the most potent inhibitor. However, the $\mathrm{IC}_{50}$ values are several orders of mag-

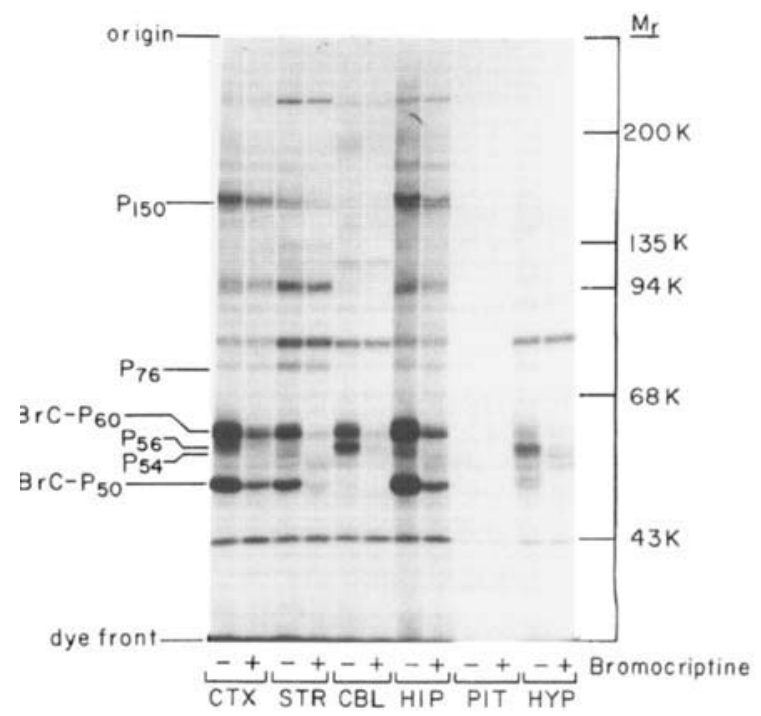

FIG. 8. Effects of bromocriptine on phosphorylation of proteins in various regions of rat brain and pituitary. Tissues were pooled from three rats, $\mathrm{P}_{2}$ fractions prepared, and subjected to phosphorylation as described in Materials and Methods. SDS-gel electrophoresis was carried out at $120 \mathrm{~V}$, $18 \mathrm{~h}$, followed by $150 \mathrm{~V}, 3 \mathrm{~h}$ on a $27-\mathrm{cm}$ long SDS-gel $6.9 \%$ acrylamide). $\mathrm{BrC}-\mathrm{P}_{50}$ and $\mathrm{BrC}-\mathrm{P}_{60}$ are indicated on left. Also indicated are other proteins whose phosphorylation appears to be affected by bromocriptine $(+, 25 \mu M)\left(P_{150}, P_{76}, P_{56}\right.$, $P_{54}$ ). Abbreviations and amounts of protein $(\mu \mathrm{g})$ applied to gel: CTX, cortex (53); STR, striatum (106); CBL, cerebellum (67); HIP, hippocampus (73); PIT, pituitary (46); HYP, hypothalamus (36). Positions of molecular weight standards are indicated at right: $200 \mathrm{~K}, 200,000 ; 135 \mathrm{~K}, 135,000 ; 94 \mathrm{~K}, 94,000$; $68 \mathrm{~K}, 68,000 ; 43 \mathrm{~K}, 43,000$. 
TABLE 2. Effects of ibotenate and fornix-fimbria lesions on guinea pig hippocampal wet weight, protein content, marker enzymes, and bromocriptinesensitive protein phosphorylation

\begin{tabular}{|c|c|c|c|c|}
\hline & \multicolumn{2}{|c|}{$\begin{array}{l}\text { Ibotenate } \\
(\mathrm{n}=7)\end{array}$} & \multicolumn{2}{|c|}{$\begin{array}{l}\text { Fornix-Fimbria } \\
\qquad(\mathrm{n}=6)\end{array}$} \\
\hline & Control & Lesion & Control & Lesion \\
\hline \multicolumn{5}{|l|}{$\begin{array}{l}\text { A. Wet weights, protein content, } \\
\text { and marker enzymes }\end{array}$} \\
\hline Hippocampus wet weight (mg) & $113 \pm 1$ & $84 \pm 6^{a}$ & $215 \pm 7^{e}$ & $208 \pm 12$ \\
\hline Protein & $115 \pm 5$ & $111 \pm 5$ & $96 \pm 2$ & $93 \pm 3$ \\
\hline GAD & $1.48 \pm 0.14$ & $0.89 \pm 0.12^{b}$ & $1.17 \pm 0.09$ & $1.12 \pm 0.07$ \\
\hline ChAT & $1.26 \pm 0.15$ & $1.31 \pm 0.14$ & $0.84 \pm 0.03$ & $0.24 \pm 0.04^{d}$ \\
\hline \multicolumn{5}{|l|}{ B. Protein phosphorylation } \\
\hline \multicolumn{5}{|l|}{$\mathrm{BrC}_{-} \mathrm{P}_{50}$} \\
\hline Basal & $3.20 \pm 0.35$ & $1.45 \pm 0.30^{b}$ & $2.89 \pm 0.26$ & $2.77 \pm 0.43$ \\
\hline Bromocriptine inhibition (\%) & $57 \pm 2$ & $46 \pm 5$ & $61 \pm 4$ & $56 \pm 5$ \\
\hline \multicolumn{5}{|l|}{ BrC- $P_{60}$} \\
\hline Basal & $2.60 \pm 0.15$ & $1.28 \pm 0.14^{c}$ & $3.01 \pm 0.16$ & $2.71 \pm 0.2$ \\
\hline Bromocriptine inhibition (\%) & $69 \pm 6$ & $65 \pm 8$ & $66 \pm 3$ & $64 \pm 4$ \\
\hline
\end{tabular}

Ibotenate was injected into one side of the hippocampus, and the hippocampus divided into control and lesion sides for analysis as described in Materials and Methods. Fornix-fimbria lesions were bilateral, and control tissue was taken from separate animals; hence, the entire hippocampal formation was employed in these studies. Marker enzymes, protein content, and phosphorylation of BrC-P $\mathrm{P}_{50}$ and $\mathrm{BrC}-\mathrm{P}_{60}$ were measured as described in Materials and Methods. Values shown are means \pm SEM of six or seven experiments, as indicated (n). All tissue samples were assayed in triplicate. Paired Student's $t$-tests were used to compare values from ibotenate-treated and control samples. Unpaired Student's $t$-tests were used to compare values from fornix-fimbria lesion and control groups. Units of measurement are as follows: Protein, $\mathrm{mg} / \mathrm{g}$ wet weight; GAD and ChAT, $\mathrm{nmol} / \mathrm{mg} \mathrm{protein} / \mathrm{min}$; protein phosphorylation, pmol ${ }^{32} \mathrm{P}$-phosphate/mg protein $/ 2 \mathrm{~min}$

${ }^{a} \mathrm{p}<0.05$, compared with control, paired analysis.

${ }^{b} \mathrm{p}<0.01$, compared with control, paired analysis.

${ }^{c} \mathrm{p}<0.005$, compared with control, paired analysis.

${ }^{d} \mathrm{p}<0.001$, compared with control, unpaired analysis.

${ }^{e}$ In fornix-fimbria lesion experiments, entire hippocampal formations were employed, whereas unilateral formations were used in ibotenate treatment experiments.

nitude higher than the concentrations required for eliciting other dopamine antagonistic effects (Clement-Cormier et al., 1974; Iversen, 1975; Seeman et al., 1976; Creese et al., 1978). Moreover, (+)-butaclamol, another potent dopamine antagonist, was not significantly different in its capacity to inhibit the phosphorylation of $\mathrm{BrC}-\mathrm{P}_{50}$ and $\mathrm{BrC}$ $\mathrm{P}_{60}$ than was the inactive enantiomer $(-)$-butaclamol. These results are in agreement with the notion that the inhibition of $\mathrm{BrC}-\mathrm{P}_{50}$ and $\mathrm{BrC}-\mathrm{P}_{60}$ phosphorylation is not mediated through dopamine receptors.

\section{DISCUSSION}

In the present study, we have shown that bromocriptine and other ergopeptines selectively inhibit phosphorylation of 50,000- and 60,000 -dalton proteins in a crude synaptosome fraction. These bromocriptine-sensitive phosphoproteins are highly enriched in the brain, particularly in the hippocampus, cerebral cortex, and caudate nucleus, and are not detectable in nonnervous tissues.

The results of the studies directed at characterizing the phosphorylation of $\mathrm{BrC}-\mathrm{P}_{50}$ and $\mathrm{BrC}-\mathrm{P}_{60}$ indicate that the reactions are very much alike. The time course of phosphorylation of BrC- $\mathrm{P}_{50}$ and $\mathrm{BrC}$ $\mathrm{P}_{60}$ and the apparent Michaelis constants $\left(K_{\mathrm{m}}\right.$ 's) for ATP are similar (Figs. 2 and 3). Phosphorylation of both proteins requires the presence of magnesium and calcium ions at approximately the same optimal concentrations (Fig. 4). In addition, phosphorylation of both $\mathrm{BrC}-\mathrm{P}_{50}$ and $\mathrm{BrC}-\mathrm{P}_{60}$ is stimulated by calmodulin (Table 1). The amino acid residue that undergoes bromocriptine-sensitive phosphorylation is threonine in both proteins. Peptide mapping analyses of $\mathrm{BrC}-\mathrm{P}_{50}$ and $\mathrm{BrC}-\mathrm{P}_{60}$ indicate that the two proteins are digested to several identical or very similar phosphopeptide fragments, suggesting a homology between the two proteins in the primary structure in the vicinity of the phosphorylation site(s). Taken together, these observations suggest that the bromocriptine-sensitive phosphorylation of both $\mathrm{BrC}-\mathrm{P}_{50}$ and $\mathrm{BrC}-\mathrm{P}_{60}$ is catalyzed by a single $\mathrm{Ca}^{2+} /$ calmodulin-dependent protein kinase.

Although bromocriptine has been characterized as a dopaminergic agonist in other systems (Kebabian and Calne, 1979), dopamine and other dopaminergic agonists had little or no effect on the phosphorylation of $\mathrm{BrC}-\mathrm{P}_{50}$ and $\mathrm{BrC}-\mathrm{P}_{60}$. Dopaminergic 


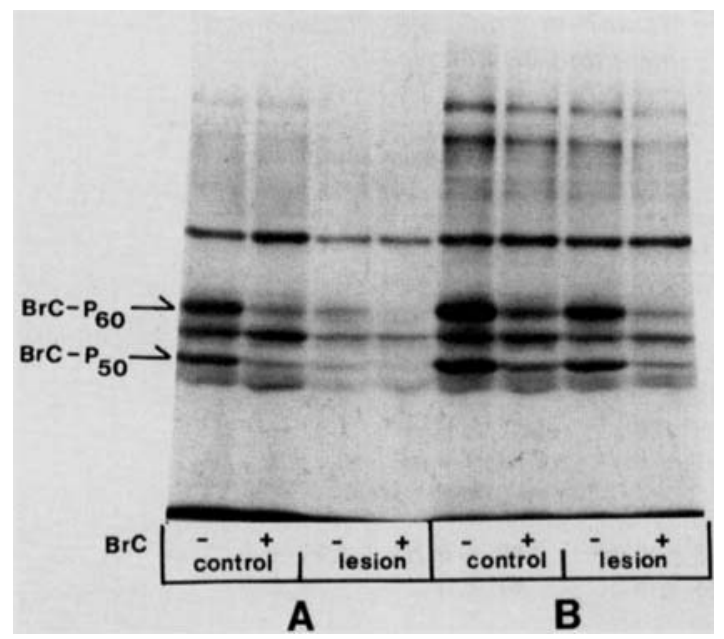

FIG. 9. Phosphoproteins in guinea pig hippocampus: effects of ibotenate-induced lesion and lesion of the fornix-fimbria on phosphorylation of proteins in homogenates of guinea pig hippocampus. Lesions were made and phosphorylation of homogenates carried out as described in Materials and Methods in the absence (-) or presence $(+)$ of $25 \mu \mathrm{M}$ bromocriptine $(\mathrm{BrC})$. Ibotenate control and lesion samples (A) are from the same animal. Fornix-fimbria control and lesion samples (B) are from two separate animals. $\mathrm{BrC}-\mathrm{P}_{60}$ and $\mathrm{BrC}-\mathrm{P}_{50}$ are indicated by arrows.

antagonists (fluphenazine, haloperidol, sulpiride) did not block the bromocriptine effect (data not shown); in fact, some dopamine antagonists mimicked the inhibitory effect of bromocriptine on $\mathrm{BrC}$ $\mathrm{P}_{50}$ and $\mathrm{BrC}-\mathrm{P}_{60}$. The effects of these agents were not, however, stereospecific. These results, and the observation that the highest specific content of the bromocriptine-sensitive phosphorylation system is in the hippocampus, a region of relatively low dopamine content (Scatton et al., 1980), militate against a dopaminergic association of the bromocriptine-sensitive protein phosphorylation system. The central effects of ergot compounds have also been attributed to their actions on $\alpha$-adrenergic and serotonergic systems (Loew et al., 1978; Rall and Schleifer, 1980). Agonists and antagonists of these systems, as well as of agonists of $\beta$-adrenergic, GABAergic, cholinergic, and histaminergic receptor systems, failed to mimic the bromocriptineinduced inhibition of phosphorylation of $\mathrm{BrC}-\mathrm{P}_{50}$ and $\mathrm{BrC}-\mathrm{P}_{60}$ (Fig. 1 and Table 3 ). These results and the observation that the peptide-containing ergots are the most potent of all the agents tested in the selective inhibition of the phosphorylation of $\mathrm{BrC}$ $\mathrm{P}_{50}$ and $\mathrm{BrC}-\mathrm{P}_{60}$ raise the possibility that the $\mathrm{BrC}$ $\mathrm{P}_{50}$ and $\mathrm{BrC}-\mathrm{P}_{60}$ phosphorylation systems may be associated with a specific receptor for ergopeptines or for a particular peptide identical or analogous to the peptide moiety of bromocriptine. Whether there is an endogenous substance that produces the inhibitory effect of bromocriptine on the protein phosphorylation is an interesting question that remains to be investigated.

In studies directed at elucidating the cellular localization of the bromocriptine-sensitive protein kinase system, we found that transection of the fornix-fimbria, which carries cholinergic, serotonergic, noradrenergic, histaminergic, and dopaminergic inputs to the hippocampus (Lewis et al., 1967; Storm-Mathisen and Guldberg, 1974; Barbin et al., 1976; Scatton et al., 1980), did not affect the phosphorylation of $\mathrm{BrC}-\mathrm{P}_{50}$ and $\mathrm{BrC}-\mathrm{P}_{60}$, indicating that
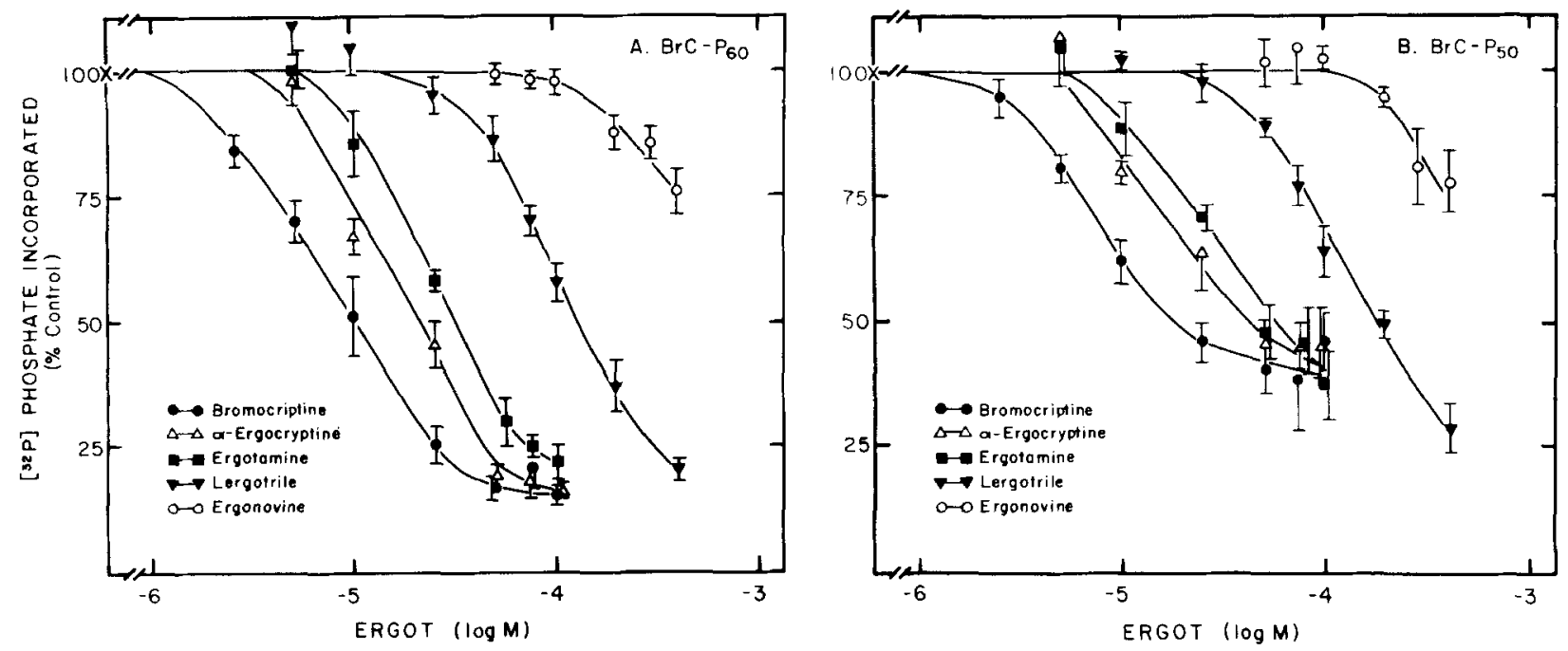

FiG. 10. Effects of various ergot derivatives on phosphorylation of $B r C-P_{50}$ and $B r C-P_{60}$. Aliquots of a $P_{2}$ fraction of rat cortex were phosphorylated in the presence of various concentrations of ergot derivatives as indicated on abscissa (log $M$ ). Relative incorporation of ${ }^{32} \mathrm{P}$-phosphate into $\mathrm{BrC}-\mathrm{P}_{60}(\mathbf{A})$ and $\mathrm{BrC}-\mathrm{P}_{50}(\mathrm{~B})$ was determined by scanning densitometry of autoradiographs, and is expressed as \% control (X). Data are from four separate experiments; error bars represent \pm SEM. (O), Bromocriptine; $(\triangle)$, $\alpha$-ergocriptine; $(\boldsymbol{\square})$, ergotamine; $(\boldsymbol{\nabla})$, lergotrile; $(O)$, ergonovine. 
TABLE 3. $I C_{50}$ values for various agents on phosphorylation of $B r C-P_{50}$ and $B r C-P_{60}$

\begin{tabular}{|c|c|c|}
\hline \multirow[b]{2}{*}{ Agent } & \multicolumn{2}{|c|}{$\mathrm{IC}_{50}(\mu M)$} \\
\hline & $\mathrm{BrC}-\mathrm{P}_{60}$ & $\mathrm{BrC}-\mathrm{P}_{50}$ \\
\hline \multicolumn{3}{|l|}{ Ergot derivatives } \\
\hline Bromocriptine & 8 & 9 \\
\hline Dihydroergocriptine & 14 & 12 \\
\hline$\alpha$-Ergocriptine & 14 & 22 \\
\hline Ergotamine & 26 & 31 \\
\hline Lergotrile & 103 & 115 \\
\hline Methysergide & $>400$ & $>400$ \\
\hline Ergonovine & $>400$ & $>400$ \\
\hline \multicolumn{3}{|l|}{ Dopaminergic antagonists } \\
\hline Spiroperidol & 36 & 32 \\
\hline Haloperidol & 83 & 87 \\
\hline Fluphenazine & 83 & 79 \\
\hline Trifluoperazine & 105 & 93 \\
\hline Thioridazine & 87 & 200 \\
\hline Chlorpromazine & 100 & 110 \\
\hline (+)-Butaclamol & 151 & 200 \\
\hline (-)-Butaclamol & 120 & 158 \\
\hline Metoclopramide & $>400$ & $>400$ \\
\hline Molindone & $>400$ & $>400$ \\
\hline Sulpiride & - & - \\
\hline \multicolumn{3}{|l|}{$\alpha$-Adrenergic agents } \\
\hline Yohimbine & 151 & 145 \\
\hline Phentolamine & $>400$ & 210 \\
\hline Clonidine & - & - \\
\hline Phenylephrine & - & - \\
\hline \multicolumn{3}{|l|}{$\beta$-Adrenergic antagonist } \\
\hline Propranolol & 100 & 158 \\
\hline \multicolumn{3}{|l|}{ Serotonergic agents } \\
\hline Methysergide & $>400$ & $>400$ \\
\hline Quipazine & $>400$ & $>400$ \\
\hline
\end{tabular}

Aliquots of $\mathrm{P}_{2}$ fraction prepared from rat cortex were phosphorylated in the presence of several concentrations of each agent listed using standard procedures described in Materials and Methods. $\mathrm{IC}_{50}$ values for each agent were determined graphically from plots of $\%$ control phosphorylation vs. log concentration agent as the concentration of the agent required to cause $50 \%$ of the maximal inhibition produced by $200 \mu M$ bromocriptine (see Fig. 10). BrC- $\mathrm{P}_{60}$ maximal inhibition $=85 \%$ of total; BrC- $\mathrm{P}_{50}$ maximal inhibition $=62.5 \%$ of total. $\mathrm{IC}_{50}$ values are listed as micromolar $(\mu M)$ concentrations. $>400$ signifies that some inhibition of phosphorylation was observed at $400 \mu M$ test agent, but was $<50 \%$ of maximal inhibition; $(-)$ signifies that no effect on phosphorylation was observed at maximum concentration of agent tested $(400 \mu M)$.

nerve terminals derived from these tracts do not contribute significantly to the phosphorylation of the two phosphoproteins. However, phosphorylation of BrC- $\mathrm{P}_{50}$ and BrC- $\mathrm{P}_{60}$ and a number of other hippocampal proteins was significantly reduced following intrahippocampal injection of ibotenate. The observed effects of ibotenate on protein phosphorylation are qualitatively similar to those of Sieghart et al. (1980), who reported that injections of a similar toxin, kainic acid, into the rat striatum resulted in a general reduction of calcium-dependent protein kinase activity due to the destruction of neuronal cell bodies. Moreover, we have recently found that the bromocriptine-sensitive protein phosphoryla- tion system is highly enriched in a postsynaptic density fraction prepared from rat brain according to the procedures described by Cohen et al. (1977) (unpublished results). Taken together, these results suggest that the reduced phosphorylation of $\mathrm{BrC}$ $\mathrm{P}_{50}$ and $\mathrm{BrC}-\mathrm{P}_{60}$ following ibotenate treatment results from the destruction of neuronal cell bodies in the hippocampus that contain the bromocriptinesensitive protein phosphorylation system. A glial cell association of the system appears unlikely, since a general proliferation of glial cells is observed following ibotenate treatment (Fisher et al., 1981). Nor is it likely that a major association exists between the bromocriptine-sensitive phosphorylation system and the ventral (perforant) pathway, since this fiber tract would be spared the effects of ibotenate (Schwarcz et al., 1979).

Calcium- and calmodulin-stimulated protein phosphorylation in brain tissues has been described by a number of investigators (DeLorenzo, 1976; Schulman and Greengard, 1978; Grab et al., 1981; Kennedy et al., 1983). In the course of our studies, we attempted to compare the bromocriptine-sensitive 50,000- and 60,000-dalton phosphoproteins with the calcium-dependent phosphoproteins of similar electrophoretic mobilities described by these authors. We found that $\mathrm{BrC}-\mathrm{P}_{50}$ and $\mathrm{BrC}-\mathrm{P}_{60}$ comigrated on one-dimensional SDS gels with the 51,000- and 62,000-dalton $\mathrm{Ca}^{2+} /$ calmodulin-stimulated phosphoproteins in crude synaptosomal preparations reported by Schulman and Greengard (1978) and with those in isolated postsynaptic densities reported by Grab et al. (1981). Bromocriptine also inhibited phosphorylation of the proteins in these preparations (data not shown). Recently, these phosphoproteins have been shown to copurify with calcium-dependent synapsin I kinase activity (Kennedy et al., 1983). We also prepared a brain homogenate according to the procedure described by DeLorenzo and coworkers (1977) and tested the effects of bromocriptine on phosphorylation of proteins in this fraction. We found that $\mathrm{BrC}-\mathrm{P}_{50}$ and BrC- $\mathrm{P}_{60}$ comigrated with prominent phosphoproteins termed DPH-M and DPH-L in the DeLorenzo preparation; however, phosphorylation of these proteins was only slightly inhibited by the presence of bromocriptine $(100 \mu M)$ in the phosphorylation assay carried out as described by DeLorenzo et al. (1977). Under the conditions of our standard phosphorylation assay, bromocriptine exhibited no effect on the phosphorylation of DPH-L or DPH-M. DPH $(400 \mu M)$, which inhibits phosphorylation of DPH-L and DPH-M, caused only a slight inhibition of phosphorylation of $\mathrm{BrC}-\mathrm{P}_{50}$ and $\mathrm{BrC}-\mathrm{P}_{60}$ (unpublished observations). Moreover, DPH-L and DPH$M$ have been reported to be phosphorylated mainly on serine residues $(69-75 \%)$, with the remainder occurring on threonine residues (DeLorenzo et al., 1977). Interestingly, BrC- $\mathrm{P}_{50}$ and $\mathrm{BrC}-\mathrm{P}_{60}$ exhibited 
almost exactly the opposite proportions. That is, phosphorylation was predominantly on threonine residues (approximately 75\%), with the remainder on serine residues. However, only the threonine phosphorylation was bromocriptine-sensitive (Fig. 5). Burke and DeLorenzo (1981) have reported that the 50,000- and 60,000-dalton phosphoprotein regions are comprised of a number of phosphoproteins, including $\alpha$ - and $\beta$-tubulin and their kinases. We compared $\mathrm{BrC}-\mathrm{P}_{50}$ and $\mathrm{BrC}-\mathrm{P}_{60}$ with purified tubulin and found that they did not comigrate on one-dimensional SDS gels (unpublished observations). Kennedy and coworkers (1983) reported that tubulin is distinct from the components of the synapsin I kinase system. Thus we conclude that although $\mathrm{BrC}-\mathrm{P}_{60}$ and $\mathrm{BrC}-\mathrm{P}_{50}$ have molecular weights in SDS in the same range as DPH-L and DPH-M described by DeLorenzo and coworkers, they are not identical to the DPH-sensitive phosphoproteins. However, it is possible that these phosphoproteins may account for some of the bromocriptine-insensitive phosphoserine residues present in our preparations.

The functional significance of the state of phosphorylation of $\mathrm{BrC}-\mathrm{P}_{50}$ and $\mathrm{BrC}-\mathrm{P}_{60}$ is not at present known. Bromocriptine, like other neurotransmitterrelated agents, is believed to elicit pharmacological effects by acting on a receptor on the cell surface (Kebabian and Calne, 1979). Compatible with this notion is recent evidence, obtained using brain slices and neuronal cell cultures, which suggests that bromocriptine-sensitive phosphorylation of BrC- $\mathrm{P}_{50}$ and BrC- $\mathrm{P}_{60}$ may occur on the cell exterior (unpublished observations). Since there is good evidence that ATP is released from nerve terminals in response to membrane depolarization (McIlwain, 1972; Kuroda and McIlwain, 1974; White, 1977; Burnstock, 1981), it is conceivable that BrC- $\mathrm{P}_{50}$ and BrC- $\mathrm{P}_{60}$ phosphorylation is involved in mediating certain of the synaptic effects of released ATP, which are yet to be defined.

Acknowledgments: This work was supported in part by an H. H. Rackham Faculty Research Grant (to T.U.). C.A.S. was supported by an NIH Predoctoral Training Grant (GM 07767), a Scottish Rite Dissertation Fellowship, and a Dalton Fellowship. We thank Ms. Mary Roth for excellent assistance in the preparation of this manuscript.

\section{REFERENCES}

Barbin G., Garbarg M., Schwartz J.-C., and Storm-Mathison J. (1976) Histamine synthesizing afferents to the hippocampal region. $J$. Neurochem. 26, 259-263.

Beemon K. and Hunter T. (1978) Characterization of Rous sarcoma virus src gene products synthesized in vitro. $J$. Virol. $28,551-566$.

Burke B. E. and DeLorenzo R. J. (1981) $\mathrm{Ca}^{2+}$ - and calmodulinstimulated endogenous phosphorylation of neurotubulin. Proc. Natl. Acad. Sci. USA 78, 991-995.
Burnstock G. (1981) Neurotransmitters and trophic factors in the autonomic nervous system. J. Physiol. 313, 1-35.

Clement-Cormier Y. C., Kebabian J. W., Petzold G. L., and Greengard P. (1974) Dopamine-sensitive adenylate cyclase in mammalian brain: a possible site of action of antipsychotic drugs. Proc. Natl. Acad. Sci. USA 71, 1113-1117.

Cohen P. (1982) The role of protein phosphorylation in neural and hormonal control of cellular activity. Nature 296, 613-620.

Cohen R. S., Blomberg F., Berzins K., and Siekevitz P. (1977) Structure of postsynaptic densities isolated from dog cerebral cortex. I. Overall morphology and protein composition. J. Cell Biol. 74, 181-203.

Cornish-Bowden A. (1979) Fundamentals of Enzyme Kinetics, pp. 26-27. Butterworths, Boston.

Creese I., Burt D. R., and Snyder S. H. (1978) Biochemical actions of neuroleptic drugs: focus on the dopamine receptor, in Handbook of Psychopharmacology, Vol. 10: Neuroleptics and Schizophrenia (Iversen L. L., Iversen S. D., and Snyder S. H, ed), pp. 37-39. Plenum Press, New York.

Daly J. W., McNeal E., Partington C., Neuwirth M., and Creveling C. R. (1980) Accumulations of cyclic AMP in adeninelabeled cell-free preparations from guinea pig cerebral cortex: role of $\alpha$-adrenergic and $\mathrm{H}_{1}$-histaminergic receptors. J. Neurochem. 35, 326-337.

DeLorenzo R. J. (1976) Calcium-dependent phosphorylation of specific synaptosomal fraction proteins: possible role of phosphoproteins in mediating neurotransmitter release. Biochem. Biophys. Res. Commun. 71, 590-597. .

DeLorenzo R. J. (1980) Role of calmodulin in neurotransmitter release and synaptic function. Ann. NYAcad.Sci. 356, 92-109.

DeLorenzo R. J., Emple G. P., and Glaser G. H. (1977) Regulation of the level of endogenous phosphorylation of specific brain proteins by diphenylhydantoin. J. Neurochem. 28, 21-30.

DeLorenzo R. J., Freedman S. D., Yohe W. B., and Maurer S. C. (1979) Stimulation of $\mathrm{Ca}^{2+}$-dependent neurotransmitter release and presynaptic nerve terminal protein phosphorylation by calmodulin and a calmodulin-like protein isolated from synaptic vesicles. Proc. Natl. Acad. Sci. USA $76,1838-1842$.

Dingledine R., Dodd J., and Kelly J. S. (1980) The in vitro brain slice as a useful neurophysiological preparation for intracellular recording. $J$. Neurosci. Methods 2, 323-362.

Eckhart W., Hutchinson M. A., and Hunter T. (1979) An activity phosphorylating tyrosine in polyoma $\mathrm{T}$ antigen immunoprecipitates. Cell 18, 925-933.

Fisher S. K., Boast C. A., and Agranoff B. W. (1980) The muscarinic stimulation of phospholipid labeling in hippocampus is independent of its cholinergic input. Brain Res. 189, 284-288.

Fisher S. K., Frey K. A., and Agranoff B. W. (1981) Loss of muscarinic receptors and of stimulated phospholipid labeling in ibotenate-treated hippocampus. J. Neurosci. 1 , $1407-1413$.

Fonnum F. (1975) A rapid radiochemical method for the determination of choline acetyltransferase. J. Neurochem. 24, 407-409.

Fuxe K., Bredholm B. B., Ogren S.-O., Agnati L. F., Hokfelt T., and Gustafsson J.-A. (1978) Ergot drugs and central monoaminergic mechanisms: a histochemical, biochemical, and behavioral analysis. Fed. Proc. 37, 2181-2191.

Glass D. B. and Krebs E. G. (1980) Protein phosphorylation catalyzed by cyclic AMP-dependent and cyclic GMP-dependent protein kinases. Annu. Rev. Pharmacol. Toxicol. 20, 363-388.

Grab K. J., Carlin R. K., and Siekevitz P. (1981) Function of calmodulin in postsynaptic densities. 1I. Presence of a calodulin-activatable protein kinase activity. J. Cell Biol. 89, $440-448$.

Greengard P. (1981) Intracellular signals in the brain, in The 
Harvey Lectures, Series 75, pp. 277-331. Academic Press, New York.

Huttner W. and Greengard P. (1979) Multiple phosphorylation sites in protein I and their differential regulation by cyclic AMP and calcium. Proc. Natl. Acad. Sci. USA 76, 54025406.

Iversen L. L. (1975) Dopamine receptors in the brain. Science $188,1084-1089$.

Kebabian J. W. and Calne D. B. (1979) Multiple receptors for dopamine. Nature 277, 93-96.

Kennedy M. B., McGuinness 'T., and Greengard P. (1983) A calcium/calmodulin-dependent protein kinase from mammalian brain that phosphorylates synapsin I: partial purification and characterization. J. Neurosci. 3, 818-831.

Kohler C., Scharcz R., and Fuxe K. (1979) Intrahippocampal injections of ibotenic acid provide histological evidence for a neurotoxic mechanism different from kainic acid. Neurosci. Lett. 15, 223-228.

Krebs E. G. and Beavo J. A. (1979) Phosphorylation-dephosphorylation of enzymes. Annu. Rev. Biochem. 48, 923-959.

Kuroda Y. and McIlwain H. (1974) Uptake and release of adenine derivatives at beds of mammalian cortical synaptosomes in a superfusion system. J. Neurochem. 22, 691-699.

Lewis P. R., Shute C. C. D., and Silver A. (1967) Confirmation from choline acetylase of a massive cholinergic innervation to the rat hippocampus. J. Physiol. (Lond.) 191, 215-224.

Loew D. M., vanDeusen E. B., and Meier-Ruge W. (1978) Effects on the central nervous system, in Handbook of Experimental Pharmacology, Vol. 49: Ergot Alkaloids and Related Compounds (Berde B. and Schild H. O., eds), pp. 421-531. Springer Verlag, New York.

Lowry O. H., Rosebrough N. J., Farr A. L., and Randall R. J. (1951) Protein measurement with the Folin phenol reagent. J. Biol. Chem. 193, 265-275.

McIlwain H. (1972) Regulatory significance of the release and actions of adenine derivatives in cerebral systems. Biochem. Soc. Symp. 36, 69-85.

Nanninga L. B. and Kempen R. (1971) Role of magnesium and calcium in the first and second contraction of glycerin-extracted muscle fibers. Biochemistry 10, 2449-2456.

Rall T. W. and Schleifer L. S. (1980) Oxytocin, prostaglandins, ergot alkaloids and other agents, in The Pharmacological Basis of Therapeutics (Gilman, A. G., Goodman L. S., and Gilman A., eds), pp. 935-950. Macmillan, New York.

Scatton B., Simon H., Lemoal M., and Bischoff S. (1980) Origin of dopaminergic innervation of the rat hippocampal formation. Neurosci. Lett. 18, 125-131.

Schulman H. and Greengard P. (1978) Stimulation of brain membrane protein phosphorylation by calcium and an endogenous heat-stable protein. Nature 271, 478-479.

Schwarcz R. T., Hokfelt T., Fuxe K., Jonsson M., Goldstein M., and Terenius L. (1979) Ibotenic acid-induced neuronal degeneration: a morphological and neurochemical study. Exp. Brain Res. 37, 199-216.

Seeman P., Lee T., Chau-Wong M., and Wong K. (1976) Antipsychotic drug doses and neuroleptic/dopamine receptors. Nature 261, 717-719.

Sieghart W., Schulman H., and Greengard P. (1980) Neuronal localization of $\mathrm{Ca}^{2+}$-dependent protein phosphorylation in brain. J. Neurochem. 34, 548-553.

Storm-Mathisen J. (1972) Glutamate decarboxylase in the rat hippocampal region after lesions of the afferent fibre systems. Evidence that the enzyme is localized in intrinsic neurones. Brain Res. 40, 215-235.

Storm-Mathisen J. and Guldberg H. C. (1974) 5-Hydroxytryptamine and noradrenaline in the hippocampal region: effects of transection of afferent pathways on endogenous levels, high affinity uptake, and some transmitter related enzymes. J. Neurochem. 22, 793-803.

Takai Y., Kishimoto A., Iwasa Y., Kawahara Y., Mori T., and Nishizuka Y. (1979) Calcium-dependent activation of a multifunctional protein kinase by membrane phospholipids. $J$. Biol. Chem. 254, 3692-3695.

Ueda T. and Greengard P. (1977) Adenosine $3^{\prime}: 5^{\prime}$-monophosphate-regulated phosphoprotein system of neuronal membranes. 1. Solubilization, purification and some properties of an endogenous phosphoprotein. J. Biol. Chem. 252, $5155-5163$.

Ueda T., Maeno H., and Greengard P. (1973) Regulation of endogenous phosphorylation of specific proteins in synaptic membrane fractions from rat brain by adenosine $3^{\prime}: 5^{\prime}$-monophosphate. J. Biol. Chem. 248, 8295-8305.

White T. D. (1977) Direct detection of depolarisation-induced release of ATP from a synaptosomal preparation. Nature 267, 67-68.

Wrenn R. W., Katoh N.; Wise B. C., and Kuo J. F. (1980) Stimulation by phosphatidylserine and calmodulin of calciumdependent phosphorylation of endogenous proteins from cerebral cortex. J. Biol. Chem. 255, 12042-12046. 